This is the final peer-reviewed accepted manuscript of:

Bedini A, Baiula M, Vincelli G, Formaggio F, Lombardi S, Caprini M, Spampinato S. Nociceptin/orphanin FQ antagonizes lipopolysaccharide-stimulated proliferation, migration and inflammatory signaling in human glioblastoma U87 cells. Biochem Pharmacol. 2017 Sep 15;140:89104.

The final published version is available online at: $\mathrm{http} / / / \mathrm{dx}$.doi.org/10.1016/i.bcp.2017.05.021

Rights / License:

The terms and conditions for the reuse of this version of the manuscript are specified in the publishing policy. For all terms of use and more information see the publisher's website.

This item was downloaded from IRIS Università di Bologna (https://cris.unibo.it/)

When citing, please refer to the published version. 


\section{Nociceptin/orphanin FQ antagonizes lipopolysaccharide-stimulated proliferation, migration and inflammatory signaling in human glioblastoma U87 cells}

Andrea Bedini ${ }^{1}$, Monica Baiula ${ }^{1}$, Gabriele Vincelli ${ }^{2}$, Francesco Formaggio, Sara Lombardi, Marco Caprini, Santi Spampinato*

Department of Pharmacy and Biotechnology, University of Bologna, Irnerio 48, 40126 Bologna, Italy

*Corresponding author at: Department of Pharmacy and Biotechnology, University of Bologna, Irnerio 48, 40126 Bologna, Italy.

E-mail address: santi.spampinato@unibo.it

${ }^{1}$ These authors contributed equally to this work

${ }^{2}$ Present address: Department of Radiation Oncology, Robert Wood Johnson Medical School, Rutgers Cancer Institute of New Jersey, New Brunswick, NJ 08903, USA

Category: Inflammation and Immunepharmacology

Abbreviations: 7-AAD, 7-amino-actynomicin; Annexin-PE, phycoerythrin-conjugated annexin V; AP-1, activator protein 1; DAMPs, damage-associated molecular patterns; ERK 1/2, extracellular signal-regulated kinase 1/2; GPCRs, G-protein coupled receptors; HMGB1, high mobility group box 1 ; IL-1 $\beta$, interleukin $1 \beta$; IrN/OFQ, immunoreactive-nociceptin; LPS, lipopolysaccharide; MAPKs, mitogen-activated protein kinases; $\mathrm{N} / \mathrm{OFQ}$, nociceptin/orphanin FQ; NF-KB, nuclear factor- $\mathrm{B}$; NOPr, nociceptin receptor; PAMPs, pathogenassociated molecular patterns; PBS, phosphate-buffered saline; PKC, protein kinase C; PP2, (4-amino-5-(4chlorophenyl)-7-(t-butyl)pyrazolo[3,4-d]pyrimidine; PTX, pertussis toxin; RIA, radioimmunoassay; SiRNA, Small interfering RNA; TLR, Toll-like receptor; TBS-T, Tris-HCl, NaCl, Tween 20; TRAF6, TNFR-associated factor

This item was downloaded from IRIS Università di Bologna (https://cris.unibo.it/)

When citing, please refer to the published version. 
6.

\section{Abstract}

Glioblastoma is among the most aggressive brain tumors and has an exceedingly poor prognosis. Recently, the importance of the tumor microenvironment in glioblastoma cell growth and progression has been emphasized. Toll-like receptor 4 (TLR4) recognizes bacterial lipopolysaccharide (LPS) and endogenous ligands originating from dying cells or the extracellular matrix involved in host defense and in inflammation. Gprotein coupled receptors (GPCRs) have gained interest in anti-tumor drug discovery due to the role that they directly or indirectly play by transactivating other receptors, causing cell migration and proliferation. A proteomic analysis showed that the nociceptin receptor (NOPr) is among the GPCRs significantly expressed in glioblastoma cells, including U87 cells. We describe a novel role of the peptide nociceptin (N/OFQ), the endogenous ligand of the NOPr that counteracts cell migration, proliferation and increase in IL-1 $\beta$ mRNA elicited by LPS via TLR4 in U87 glioblastoma cells. Signaling pathways through which N/OFQ inhibits LPSmediated cell migration and elevation of $\left[\mathrm{Ca}^{2+}\right]_{i}$ require $\beta$-arrestin 2 and are sensitive to TNFR-associated factor 6, c-Src and protein kinase C (PKC). LPS-induced cell proliferation and increase in IL-1 $\beta$ mRNA are counteracted by N/OFQ via $\beta$-arrestin 2 , PKC and extracellular signal-regulated kinase $1 / 2$; furthermore, the contributions of the transcription factors NF- $k B$ and AP-1 were investigated. Independent of LPS, N/OFQ induces a significant increase in cell apoptosis. Contrary to what observed in other cell models, a prolonged exposure to this endotoxin did no promote any tolerance of the cellular effects above described, including

This item was downloaded from IRIS Università di Bologna (https://cris.unibo.it/)

When citing, please refer to the published version. 
NOPr down-regulation whilst N/OFQ loses its inhibitory role.

Keywords: Apoptosis; Cell migration; Cell proliferation; Glioblastoma; Nociceptin

\section{Introduction}

Glioblastoma is the highest grade of glioma and is among the most aggressive, angiogenic and invasive brain tumors with an exceedingly poor prognosis [1]. Glioblastomas are histologically heterogeneous, containing cancerous cells mostly derived from astrocytes and oligodendrocytes [2]. Current treatments include surgery followed by radiotherapy and chemotherapy; however, these treatments frequently fail, and relapses are observed in the majority of patients [3].

Several genetic alterations contribute to the activation of survival signaling pathways and confer resistance to apoptosis and therapy [4]. Recent studies have emphasized the importance of the tumor microenvironment in glioblastoma cell growth and progression [5] and the contribution of inflammatory mediators [6]. Mounting evidence supports that chronic inflammation, which activates cytokines such as interleukin $1 \beta$ (IL-1 $\beta)$, is a crucial event in carcinogenesis and tumor progression $[7,8]$. Inflammatory mediators act via intracellular signaling cascades, which regulate hubs of transcriptional pathways that contribute to the survival and rapid growth of malignant cells, with the number of inflammatory stimuli far exceeding the limited list of transcription factors that they activate [9]. Therefore, inhibiting transcription factors that act at the intersection of several deregulated signaling pathways should hold the promise of a better understanding of cancer progression [10]. Among them, nuclear factor (NF)- $\mathrm{kB}$ and activator protein 1 (AP-1) are critical regulators of inflammation and cancer. NF- $\mathrm{KB}$ has been found to be constitutively

This item was downloaded from IRIS Università di Bologna (https://cris.unibo.it/)

When citing, please refer to the published version. 
activated in human glioblastomas [10], where it regulates the transcription of more than 200 dependent genes, including cell survival genes, pro-inflammatory cytokines, chemokines and growth factors that contribute to cell proliferation and to counteracting cell apoptosis. Most receptors, such as interleukin-1 receptor, Toll-like receptors (TLRs) and T-cell receptors, activate the NF-KB [11] and AP-1 pathways [12].

TLRs are membrane-bound pattern-recognition receptors that sense a variety of microbialspecific motifs named pathogen-associated molecular patterns (PAMPs) to trigger an innate immune response and also recognize damage-associated molecular patterns (DAMPs) released from dying and injured cells, which play a fundamental role in host defense and inflammation [13]. TLR activation by DAMPs initiates rounds of tissue damage and inflammation, leading to chronic inflammation associated with cancer and other diseases. Furthermore, necrotic cells, occurring in cancer, passively release a variety of DAMPs such as high mobility group box 1 (HMGB1) [14].

TLR 4 recognizes bacterial lipopolysaccharide (LPS) and several endogenous DAMPs [14] that trigger the activation of complex, cell-dependent molecular reactions mediated by an increase in $\left[\mathrm{Ca}^{2+}\right]_{\mathrm{i}}$ and the sequential activation of several signaling pathways, including phospholipase C, c-Src kinase, protein kinase $\mathrm{C}$ (PKC) and mitogen-activated protein kinases (MAPKs), c-Jun N-terminal kinase (JNK), extracellular signal-regulated kinase 1/2 (ERK 1/2) and p38 MAPK, which may lead to AP-1 and NF-אB activation, mediating cell proliferation and motility [15].

TNFR-associated factor 6 (TRAF6) is a key adaptor of TLR4 downstream signaling [16]. It has been proposed that G-protein coupled receptor (GPCR) regulator $\beta$-arrestin 2 may act as negative regulator of TLR signaling by associating to TRAF6 and preventing signal transduction [17].

Calcium plays a key role in intracellular signaling and regulates several tumor cell processes [18]; interestingly, low-voltage activated T-type channels are overexpressed in glioblastoma cells, where they contribute to controlling the proliferation and migration of tumor cells and to modulating signaling pathways

This item was downloaded from IRIS Università di Bologna (https://cris.unibo.it/)

When citing, please refer to the published version. 
linked to anti-apoptotic functions [19].

Overwhelming evidence now implicates G-protein coupled receptors (GPCRs), G proteins and their downstream signaling targets in cancer initiation and progression, where they can influence aberrant cell growth and survival and contribute to the establishment and maintenance of a permissive tumor microenvironment [20].

Friesen et al. [21] have reported that glioblastoma cells express mu-opioid receptors, members of the GPCR superfamily, which, by reducing CAMP, sensitize chemo- and radio-resistant glioblastoma cells for doxorubicin-induced apoptosis.

A recent proteomic analysis of GPCRs expressed in glioblastoma cells has shown that the nociceptin receptor (NOPr, also known as ORL1, opioid receptor-like 1) is among the GPCRs significantly expressed in glioblastoma cells, including U87 cells [22].

The role played by NOPr has been poorly explored in glioblastoma proliferation and signaling. The endogenous ligand nociceptin, also known as orphanin FQ (N/OFQ), is a heptadecapeptide that shares sequence homology with the opioid peptide dynorphin but displays a very low potency in binding to the classical opioid receptors and has a distinct pharmacological profile $[23,24]$. The binding of N/OFQ to NOPr influences glial cell functions and may counteract the production of proinflammatory cellular events [25] whereas it is up regulated by inflammatory mediators in astrocytes [26].

In this study, we characterized the inhibitory effects of N/OFQ via NOPr on TLR4-induced cell migration, proliferation, increase of $\left[\mathrm{Ca}^{2+}\right]_{i}$ and IL-1 $1 \beta$ gene expression in U87 human glioblastoma cells. Signaling pathways through which N/OFQ inhibits LPS-mediated cell migration, elevation of $\left[\mathrm{Ca}^{2+}\right]_{i}$ and cell proliferation are sensitive to $\beta$-arrestin 2 and TRAF6 and require c-Src and PKC kinases. Increase in IL-1 $\beta$ mRNA induced by LPS is counteracted by N/OFQ via $\beta$-arrestin 2 , PKC and ERK $1 / 2$; furthermore, the contribution of transcription factors NF-kB and AP-1 was investigated. Independent of LPS, N/OFQ induces a significant

This item was downloaded from IRIS Università di Bologna (https://cris.unibo.it/)

When citing, please refer to the published version. 
increase in cell apoptosis.

Prolonged activation of TLR4 by LPS may induce a state of tolerance that reprograms cellular responses to prevent an overstimulation by endotoxins [27]. Conversely, in U87 glioblastoma cells a prolonged exposure to LPS does not cause any apparent tolerance, as this agent still promotes cell migration and proliferation and elevates IL-1 $\beta$ mRNA whereas down-regulates NOPr expression; thus, N/OFQ loses its inhibitory role on LPS-mediated cellular functions mentioned above.

\section{Materials and Methods}

\subsection{Cell culture, reagents and antibodies}

Human glioblastoma U87 cells were obtained from American Type Culture Collection (Rockville, MD, USA). Cells were grown in minimal essential medium (Lonza Group Ltd, Basel, Switzerland) supplemented with $2 \mathrm{mM}$ L-Glutamine (Lonza), 1x non-essential aminoacids (Life Technologies, Monza, Italy) and 1x antibiotic-antimycotic solution (Life Technologies) (defined cell culture medium), containing $10 \%$ fetal bovine serum (Life Technologies) and cultured at $37^{\circ} \mathrm{C}$ in a humidified atmosphere of $5 \% \mathrm{CO}_{2}$. Cells from passages 10 to 20 were used. LPS from E. coli (0111:B4), Actinomycin D, GF109203X, Gö6976, PD98059, LY294002, SB203580, pertussis toxin from Bordetella pertussis (PTX) and PP2 were purchased from SigmaAldrich (Milan, Italy) and dissolved in dimethylsulphoxide (DMSO); the final concentration of DMSO was less than $0.1 \%$ and did not cause any significant effect on the activities tested in this study (data not shown). N/OFQ, [NPhe1]N/OFQ(1-13) $\mathrm{NH}_{2}$ NNC 55-0396 were from Tocris (Bristol, United Kingdom) and dissolved in cell culture medium (vehicle). Nifedipine (Tocris) was dissolved in ethanol (final concentration was $0.1 \%$ ). Small interfering RNA (siRNA) for human TLR4, TRAF6 and $\beta$-arrestin 2 or negative control siRNA (ctrsiRNA)

This item was downloaded from IRIS Università di Bologna (https://cris.unibo.it/)

When citing, please refer to the published version. 
were Silencer ${ }^{\circledR}$ select pre-designed and validated siRNA obtained from Thermo Fisher Scientific (Walthman. Ma, USA). U87 cells were transfected with siRNA or ctrsiRNA (50 nM) by using Lipofectamine ${ }^{\circledR}$ RNAiMAX (Thermo Fisher Scientific) according to the manufacturer's protocol and treatments were started $48 \mathrm{~h}$ later. The transfection efficiency of each duplex siRNA was confirmed by using Block-IT'M fluorescent oligo (Thermo Fisher Scientific). About $80-90 \%$ of cells were transfected as confirmed by flow cytometry (data not shown). Decoy oligonucleotides were purchased from Life Technologies. Anti phospho-ERK1/2, total ERK1/2, and anti phospho-PKC (pan) ( $\beta$ II Ser660) (diluted 1:1000 were from Cell Signaling Technologies (EuroClone, Pero, Italy). Anti $\beta$ actin (diluted 1:5000) was from Abcam (Cambridge, United Kingdom) and anti human TRAF6 (1 $\mu \mathrm{g} / \mathrm{ml}$ ) was from E\&D Systems (Minneapolis, MN, USA). Immunoreactive (ir)-N/OFQ was assayed employing a radioimmunoassay (RIA) kit obtained from Phoenix Pharmaceuticals, Inc. (Burlingame, CA, USA). All other reagents were of analytical grade, or of the highest purity available, purchased from Sigma-Aldrich.

\subsection{Wound healing assay}

U87 cells were seeded in $60 \mathrm{~mm}$-dishes until they reached $90 \%$ confluence. The monolayer of cells was wounded by manually scratching the surface with a sterile $200-\mu \mathrm{L}$ pipette tip to create three definite scratches. The cells were gently rinsed twice with phosphate-buffered saline (PBS) to remove non-adherent cells; serum-free cell culture medium with indicated treatments was added for $18 \mathrm{~h}$. Images were acquired using an inverted phase-contrast microscope (Nikon; $5 \times$ objective) equipped with a Nikon digital camera. Six images per treatment were measured and analyzed by TScratch program [28], a software tool for automated analysis of wound healing assays, comparing open area at 18 hours to that at 0 hours. The migration of cells toward the wounds, reflecting the degree of migration or wound healing, was expressed as percentage of cell migration calculated as follows: cell migration $(\%)=\left[\left(A_{t}\right.\right.$ oh $\left.\left.-A_{t 18 h}\right) / A_{t o h}\right] \times 100$, where, $A_{t}$ oh is the area of wound measured immediately after scratching, and $A_{t} 18 \mathrm{~h}$ is the area of wound measured $18 \mathrm{~h}$ after

This item was downloaded from IRIS Università di Bologna (https://cris.unibo.it/)

When citing, please refer to the published version. 
scratching.

\subsection{Cell proliferation assay}

Cell proliferation assay was carried out as previously described [29]. U87 cells were plated on 12-well plate and treated for $24 \mathrm{~h}$ and treated as described in the results section or maintained in cell culture medium containing $10 \%$ fetal bovine serum. $5 \mathrm{~h}$ before the end of the treatments, [methyl- ${ }^{3} \mathrm{H}$ ] Thymidine (Perkin Elmer, Milan, Italy) (50 nM final concentration) was added to serum-free cell culture medium and the plate was incubated at $37^{\circ} \mathrm{C}$. Thereafter, medium was removed and cells were washed twice with PBS. $200 \mu \mathrm{l}$ of PBS were added to each well, the cells were scraped off and centrifuged at $13,000 \mathrm{~g}$ for $3 \mathrm{~min}$ at $4^{\circ} \mathrm{C}$; supernatants were then discarded, pellets re-suspended in $500 \mu \mathrm{l}$ of cold trichloroacetic acid $(10 \% \mathrm{w} / \mathrm{v})$, incubated on ice for $20 \mathrm{~min}$ and centrifuged at $13,000 \mathrm{~g}$ for $3 \mathrm{~min}$ at $4^{\circ} \mathrm{C}$. The obtained supernatant was then discarded, pellet suspended in $500 \mu \mathrm{l}$ of cold methanol and centrifuged at $3 \mathrm{~min}$ for $13,000 \mathrm{~g}$ at $4^{\circ} \mathrm{C}$. After that, the pellet was suspended in $200 \mu \mathrm{l}$ of $\mathrm{NaOH} 1 \mathrm{~N}$ and heated at $55^{\circ} \mathrm{C}$ for $10 \mathrm{~min}$. Samples were then neutralized with $200 \mu \mathrm{l}$ of $\mathrm{HCl} 1 \mathrm{~N}$ and $350 \mu$ of the labeled DNA incubated in counting vials with $4 \mathrm{ml}$ of Filter Count scintillation liquid (Perkin Elmer Italia). Vials were vortexed and incubated overnight at room temperature and the radioactivity was determined by liquid scintillation spectrometry.

\subsection{Total RNA preparation and real-time RT-PCR analysis}

U87 cells were maintained in cell culture medium containing $10 \%$ fetal bovine serum, and, after treatments, were collected from tissue culture flasks, centrifuged (500 g for $5 \mathrm{~min}$ ) and rinsed with phosphate-buffered saline. Total cellular RNA was extracted with Trireagent ${ }^{\circ}$ (Sigma-Aldrich) and digested

with Rnase-free Dnase (Thermo Fisher Scientific) for $15 \mathrm{~min}$ at $25^{\circ} \mathrm{C}$ according to the manufacturer's

This item was downloaded from IRIS Università di Bologna (https://cris.unibo.it/)

When citing, please refer to the published version. 
instructions. A 2- $\mu$ g sample was reverse-transcribed using the High Capacity cDNA reverse transcription kit (Life Technologies) according to the manufacturer's instructions. Real-time PCR was employed for relative quantification of human IL-1 $\beta$ and human NOPr transcripts using the StepOne Instrument (Life Technologies) and the GoTaq ${ }^{\circledR}$ qPCR master mix (Promega, Madison, Wisconsin, USA). This 'hot start' reaction mix contains Taq DNA polymerase, dNTP mix, and the fluorescent dye SYBR Green I for real-time detection of doublestranded DNA. Reactions were set up in $10 \mu \mathrm{L}$ including $100 \mathrm{ng}$ of target DNA. To amplify human IL-1 $\beta$ cDNA, a sense primer (5'-CAAGGGCTTCAGGCAGGCCG-3') and an antisense primer (5'-TGAGTCCCGGAGCGTGCAGT3') were used at $0.25 \mu \mathrm{M}$ final concentration for producing a 213-bp fragment (261-474 bp; GenBank Accession no. NM_000576.2). To amplify the human NOPr cDNA, a sense primer (5'CTCAAGGTCACCATCGTGG-3') and an antisense primer (5'-AAGCCCAGGAGGATGTCC-3) were used at $0.25 \mu \mathrm{M}$ final concentration for producing a 196-bp fragment (603-799 bp; GenBank Accession no. NM_182647.3). As a control, a 169-bp fragment of the human L19 ribosomal protein gene was amplified with a sense primer (5'-CTAGTGTCCTCCGCTGTGG-3') and an antisense primer (5'-AAGGTGTTTTTCCGGCATC-3') at $0.25 \mu \mathrm{M}$ final concentration, producing a fragment (62-230 bp; GenBank Accession no. BC062709). Human IL-1 $\beta$ cDNA amplification was performed as follows: $95^{\circ} \mathrm{C}$ for $10 \mathrm{~min}$ followed by 40 cycles of $95^{\circ} \mathrm{C}$ for $30 \mathrm{~s}, 68^{\circ} \mathrm{C}$ for $30 \mathrm{~s}$, and $72^{\circ} \mathrm{C}$ for $30 \mathrm{~s}$. Human NOPr and L19 amplifications were carried out as follows: $95^{\circ} \mathrm{C}$ for 10 min followed by $40 \mathrm{cycles}$ of $95^{\circ} \mathrm{C}$ for $10 \mathrm{~s}$ and $60^{\circ} \mathrm{C}$ for $60 \mathrm{~s}$. After that, the temperature was lowered to $60^{\circ} \mathrm{C}$ for $30 \mathrm{~s}$ and the specificity of the reaction was verified by analysis of the melting curve once the appropriate doublestranded DNA melting temperature had been reached.

Relative expression of RT-PCR products was determined using the $\Delta \Delta C_{T}$ method [31]; where $C_{T}$ is the threshold cycle, i.e. the cycle number at which the sample's relative fluorescence rises above the background fluorescence and $\Delta \Delta C_{T}=\left[C_{T}\right.$ gene of interest (unknown sample) $-C_{T} L 19$ (unknown sample) $]-\left[C_{T}\right.$ gene of interest (calibrator sample) - $C_{T}$ L19 (calibrator sample)]. One of the control samples was chosen as the calibrator sample and used in each PCR. Each sample was run in triplicate and the mean $\mathrm{C}_{\mathrm{T}}$ was used in the This item was downloaded from IRIS Università di Bologna (https://cris.unibo.it/) When citing, please refer to the published version. 
$\Delta \Delta C_{T}$ equation. $L 19$ was chosen for normalization because this gene showed consistent expression relative to other housekeeping genes among the treatment groups in our experiments.

\subsection{Cell apoptosis detection}

Phycoerythrin-conjugated annexin V (annexin-PE) and 7-amino-actynomicin D (7-AAD; Guava Nexin Reagent, Merck Millipore, Darmstadt, Germany) were used to determine, by flow cytometry, the percentage of viable, early-apoptotic and late apoptotic/necrotic cells. U87 cells were maintained in cell culture medium containing $10 \%$ fetal bovine serum, and, after treatments, were collected by trypsinization, and resuspended in $100 \mu \mathrm{l}$ of complete medium; the cells were then stained with $100 \mu \mathrm{l}$ annexin V-PE and 7-AAD for 20 min at room temperature in the dark, following manufacturer's instructions, and analyzed on a Guava ${ }^{\circledR}$ easyCyte 5 flow cytometer (Merck Millipore, Vimodrone, Italy). Three populations of cells can be distinguished by this assay: viable cells (annexin V-PE and 7-AAD negative), early apoptotic cells (annexin V-PE positive and 7-AAD negative), and late stages apoptosis or necrotic cells (annexin V-PE and 7-AAD positive) [32].

\subsection{Caspase-3/7 activation assay}

U87 Cells $(10,000$ cells/well) were plated in 96-well black plate, allowed to attach and then exposed to different treatments in the presence of cell culture medium containing $10 \%$ fetal bovine serum. Afterwards, the activation of caspase-3/7 was measured by the fluorescence-based Apo-ONE ${ }^{\mathrm{TM}}$ Homogeneous Caspase3/7 Assay (Promega) following manufacturer's instructions. Briefly, $100 \mu \mathrm{l}$ of Caspase-3/7 reagent were added to each well and incubated at room temperature for $18 \mathrm{~h}$ in a plate shaker at $400 \mathrm{rpm}$; fluorescence

This item was downloaded from IRIS Università di Bologna (https://cris.unibo.it/)

When citing, please refer to the published version. 
was then measured (Ex $485 \mathrm{~nm} / \mathrm{Em} 528 \mathrm{~nm}$ ).

\subsection{Calcium microfluorometry}

Variations in intracellular free $\mathrm{Ca}^{2+}$ concentration $\left(\left[\mathrm{Ca}^{2+}\right]_{\mathrm{i}}\right)$ were monitored through ratiometric microfluorometry using the fluorescent $\mathrm{Ca}^{2+}$ detector fura-2 AM (Molecular Probes; Thermo Fisher Scientific). For microfluorometric experiments the control bath saline was $140 \mathrm{mM} \mathrm{NaCl}, 4 \mathrm{mM} \mathrm{KCl}, 2 \mathrm{mM} \mathrm{MgCl}, 2 \mathrm{mM}$

$\mathrm{CaCl}_{2}, \quad 10 \mathrm{mM} \quad$ 2-[(2-Hydroxy-1,1-bis(hydroxymethyl)ethyl)amino]ethanesulfonic $\quad$ acid, $\quad \mathrm{N}$ [Tris(hydroxymethyl)methyl]-2-aminoethanesulfonic acid, and $5 \mathrm{mM}$ glucose, $\mathrm{pH} 7.4$, with $\mathrm{NaOH}$ and osmolarity adjusted to 320 mOsm with mannitol. $\mathrm{Ca}^{2+}$ - free saline was prepared by removing $\mathrm{CaCl}_{2}$ and by adding $0.5 \mathrm{mM}$ EGTA. When using high $(100 \mathrm{mM}) \mathrm{K}^{+}$external solutions for a control test, salts were replaced equimolarly. Stock solutions of compounds under investigation were diluted in control or $\mathrm{Ca}^{2+}$-free media. Before $\mathrm{Ca}^{2+}$ measurements, low-density cultured U87 cells, seeded in coverslips, were loaded with Fura-2 AM (Sigma-Aldrich) dissolved in standard bath solution for $45 \mathrm{~min}$ at $25^{\circ} \mathrm{C}$. For microfluorometric analysis cells on coverslips were mounted on a perfusion chamber containing $100 \mu$ l of bath saline. Cells were continuously perfused at a rate of $0.5 \mathrm{ml} / \mathrm{min}$ with different solutions at room temperature $\left(22-24^{\circ} \mathrm{C}\right)$ as previously described [33]. Measurements of $\left[\mathrm{Ca}^{2+}\right]_{i}$ in single cells were performed using an inverted fluorescence microscope (Nikon Eclipse TE2000U; Nikon, Italy) equipped with a long-distance dry objective (X40) and appropriate filters. The emission fluorescence of selected cells was passed through a 510-nm narrow-band filter and acquired with a digital charge-coupled device camera (VTi; Visi-Tech International Ltd., Sunderland, UK). Monochromator settings, chopper frequency and data acquisition were controlled by QuantiCell 2000 (VisiTech). The excitation wavelength was alternated between 340 and $380 \mathrm{~nm}$ with a sampling rate of 0.25 or $0.5 \mathrm{~Hz}$. The fluorescence ratio measured at 340 and $380 \mathrm{~nm}$ (F340/F380) was used as an indicator of [Ca ${ }^{2+}$ ] i changes. The calibration of the $340 / 380$ ratio in terms of the free $\mathrm{Ca}^{2+}$ concentration was based on the

This item was downloaded from IRIS Università di Bologna (https://cris.unibo.it/)

When citing, please refer to the published version. 
procedure previously described [34].

\subsection{Western blotting analysis}

Proteins were extracted and western blotting analysis performed as previously described $[29,30]$. Briefly, U87 cells were plated into 6 -well plates until a confluence of $60-70 \%$ was reached; then, the cells were serum-starved for $16-18 \mathrm{~h}$ and subsequently exposed to different treatments in cell culture medium alone. To detect ERK1/2 phosphorylation, cells were scraped off and pelleted after 15 min of exposure whereas to detect PKC phosphorylation, cells were harvested after 60 min of exposure.

Proteins (15 $\mu \mathrm{g}$ to assay ERK1/2 or $30 \mu \mathrm{g}$ to assay PKC) were separated by SDS-PAGE on $12 \%(\mathrm{w} / \mathrm{v})$ acrylamide/bisacrylamide gels and electrotransfered onto nitrocellulose membranes. Membranes were incubated in TBS-T (20 mmol/L Tris- $\mathrm{HCl}, \mathrm{pH} 7.5,137 \mathrm{mmol} / \mathrm{L} \mathrm{NaCl}, 0.05 \%$ (v/v) Tween 20) containing 5\% (w/v) bovine serum albumin for $1 \mathrm{~h}$ at room temperature. Subsequently, the membranes were incubated for $12 \mathrm{~h}$ with the appropriate primary antibody, rinsed with TBS-T, and incubated with peroxidase-conjugated antirabbit secondary antibodies (Santa Cruz Biotechnology, Dallas, Texas, USA) at $25^{\circ} \mathrm{C}$ for $1.5 \mathrm{~h}$ and the blots were developed with Clarity ${ }^{\mathrm{TM}}$ Western ECL substrate (Bio-Rad Laboratories, Segrate, Milan, Italy). Blot images were digitally acquired by LAS3000 Imager (Fujifilm Corporation, Stamford, CT, USA) and protein expression semi-quantitatively analyzed using AIDA software (Raytest Isotopenmessgeraete GmbH, Mannheim, Germany).

\subsection{Decoy oligonucleotide approach}

The adopted transcription factor decoy oligonucleotide approach, its efficiency, and specificity are described in detail in previous papers $[35,36]$. Short, double-stranded oligonucleotides with specific binding

This item was downloaded from IRIS Università di Bologna (https://cris.unibo.it/)

When citing, please refer to the published version. 
sequences for NF-kB or AP-1 transcription factors were introduced into living cells by passive uptake during an overnight incubation ( $16 \mathrm{~h}$ ) of the cells in the presence of $160 \mathrm{nM}$ oligonucleotides and in serum-free cell culture medium. In the cells, transcription factors rather interact with the excess of decoy oligonucleotides than binding to the natural regulatory motifs of target genes. The sequences for the decoy oligonucleotides were described previously [35] (only the sense strand is given; putative binding sequences are underlined):

AP-1， 5'-TTACCTATGAGTTATCTTGTTT-3'; mu-AP-1， 5'-CCTAAGGAGAGTCAAGAGAAC-3'; NF-кB 5'AAAGTTGAGGGGACTTTCCCAGGCCT-3'; muNF-кB 5'-TATTATGTGGCTTTTCCTAGAATT-3'. Experiments were carried out in serum free-cell culture medium or in the presence of $10 \%$ fetal bovine serum as indicated in the relative figure legend. Efficiency and selectivity of decoy oligonucleotides was ascertained as described in the results (see subsection 3.6).

\subsection{Dual luciferase assay}

Dual luciferase assay was employed to evaluate LPS- and N/OFQ-mediated effects on NF-kB and AP-1 activation. U87 cells were plated into 96-well plates and co-transfected with plasmids containing reporter constructs: pGL4.74[hRLuc/TK] and pGL4.32[Luc2P/NF-kB-RE/Hygro] or pGL4.44[Luc2P/AP1-RE/Hygro] vectors (Promega) to evaluate luciferase activity following manufacturer's instructions. Cells, $24 \mathrm{~h}$ after transfection, were exposed to different treatments in cell culture medium containing $10 \%$ fetal bovine serum. Thereafter, at the end of the treatments, firefly luciferase activity and renilla luciferase activity (measured as a control) were determined by Dual-Glo ${ }^{\mathrm{TM}}$ Luciferase Reporter Assay (Promega).

\subsection{Saturation binding assay}

Radioligand binding assays were performed as previously described [37]. U87 cell membranes were

This item was downloaded from IRIS Università di Bologna (https://cris.unibo.it/)

When citing, please refer to the published version. 
prepared by homogenizing cells in $50 \mathrm{mM}$ Tris- $\mathrm{HCl}$ buffer, $\mathrm{pH}$ 7.4, containing $1 \mathrm{mM}$ EDTA, $1 \mathrm{mM}$ dithiothreitol, and $1 \mathrm{mM}$ benzamidine, with a Polytron homogenizer. After centrifugation (1000 $\mathrm{g}$ for $10 \mathrm{~min}$ at $\left.4^{\circ} \mathrm{C}\right)$, supernatants were centrifuged $\left(18000 \times \mathrm{g}\right.$ for $30 \mathrm{~min}$ at $\left.4^{\circ} \mathrm{C}\right)$ and the pellet suspended in $50 \mathrm{mM}$ Tris$\mathrm{HCl}$ buffer, $\mathrm{pH} 7.4$, containing $5 \mathrm{mM} \mathrm{MgCl}$. Protein concentration was determined by the BCA assay kit (Thermo Fisher). For saturation binding experiments, cell membranes (40 $\mu \mathrm{g} /$ assay tube) were incubated in $100 \mathrm{mM}$ Tris- $\mathrm{HCl}, \mathrm{pH} 7.4$, containing $0.3 \%$ bovine serum albumin with increasing concentrations of [ ${ }^{125}$ ] N/OFQ (150-5000 pM) (Phoenix Pharmaceuticals, Inc.). Non-specific binding was determined in the presence of [NPhe1]N/OFQ(1-13) $\mathrm{NH}_{2}(10 \mu \mathrm{M})$. After 90 min incubation at $25^{\circ} \mathrm{C}$, bound ligand was isolated by rapid filtration on Whatman GF/B filters (Schleicher \& Schuell, Dassel, Germany). Filters were washed with $20 \mathrm{~mL}$ of ice-cold $50 \mathrm{mM}$ Tris-HCl buffer, $\mathrm{pH} 7.4$, and left in scintillation fluid overnight before counting. Data were fitted by non-linear least-square regression and the GraphPad Prism software (GraphPad Software Inc., San Diego, CA, USA) was used to calculate receptor density $\left(\mathrm{B}_{\max }\right)$ and dissociation equilibrium constant $\left(\mathrm{K}_{\mathrm{d}}\right)$. Data are expressed as fmol of [ $\left.{ }^{125} \mathrm{I}\right]-\mathrm{N} / \mathrm{OFQ}$ bound and normalized to cell homogenate protein content.

\subsection{RIA}

Ir-N/OFQ was evaluated in cell culture medium and in cell homogenates by a RIA procedure. U87 cells were treated by adding the reagents directly to the medium and at the end of incubation time, aliquots of the medium $(100 \mu \mathrm{l})$ were transferred to $1.5 \mathrm{ml}$ tubes and stored at $-80^{\circ} \mathrm{C}$ until RIA procedure was carried out. Cells were rinsed with PBS and an extraction solution ( $10 \%$ acetic acid, $0.5 \mathrm{mg} / \mathrm{ml} \mathrm{BSA}, 3 \mathrm{mM}$ phenylmethylsulfonyl fluoride) was added; cells were scraped and the cell suspension was transferred to 1.5 $\mathrm{ml}$ tubes, sonicated for $\approx 20 \mathrm{~s}$, and frozen and thawed three times. Aliquots were removed for protein assay. The remaining homogenate was spun in a microcentrifuge $\left(8,000 \times \mathrm{g}, 10 \mathrm{~min}, 4^{\circ} \mathrm{C}\right)$ and aliquots of supernatant were used to evaluate the content of N/OFQ by a RIA procedure as described $[26,38]$. Ir-N/OFQ was

This item was downloaded from IRIS Università di Bologna (https://cris.unibo.it/)

When citing, please refer to the published version. 
estimated by comparison to a standard N/OFQ curve assayed with the same procedure. The detection limit was $5 \mathrm{pg} /$ tube and $\mathrm{IC}_{50}$ value of $0.20 \pm 0.05 \mathrm{ng} / \mathrm{ml}$ (mean $\pm \mathrm{SD}$ (standard deviation); $n=5$ ). The intra-assay and inter-assay coefficients of variation were $<5 \%$. Average recovery of radiolabeled N/OFQ added to cell culture medium or to cell homogenates was $85 \pm 2 \%$ and $83 \pm 4 \%(n=7)$, respectively. The amount of N/OFQ in the unknown samples was extrapolated from the standard curve using GraphPad Prism version 5.0 (GraphPad Software, Inc., San Diego, CA, USA).

\subsection{Statistical analysis}

All data are presented as mean \pm SD for the number of experiments indicated and were analyzed by oneway ANOVA followed by Newman-Keuls test. The GraphPad Prism, version 5.0 (GraphPad Software, Inc.) was used, and $\mathrm{P}$ values $<0.05$ were considered significant.

\section{Results}

3.1. Signaling pathways contributing to LPS-induced migration, proliferation and increase of $\left[\mathrm{Ca}^{2+}\right]_{i}$ in U87 cells

In these experiments, we utilized the human glioblastoma cell line U87 that constitutively expresses TLR4 [15].

Previously, it has been reported that LPS is capable of accelerating U87 cell migration in vitro [15]. To evaluate any influence of LPS-induced migration, we used a wound-healing assay. As shown in Fig. $1 \mathrm{~A}$ and 1B, LPS $(10 \mathrm{ng} / \mathrm{ml})$ stimulates cell migration. To determine the role of TLR4 and TRAF6, a protein that mediates intracellular signaling activated by TLR4 interacting with various protein kinases [16], on LPSmediated cell migration, we transfected U87 cells with a siRNA targeting TLR4 or TRAF6 or with a control

This item was downloaded from IRIS Università di Bologna (https://cris.unibo.it/)

When citing, please refer to the published version. 
siRNA. Knockdown of TLR4 and TRAF6 resulted in complete abolishment of LPS-mediated cell migration (Fig. $1 \mathrm{~A}$ and $1 \mathrm{~B})$. Western blot analysis ascertained that the expression of TLR4 was significantly reduced in U87 cells transfected with siRNA compared with the counterparts transfected with a control siRNA (Fig. 1F). Similarly, western blot analysis confirmed that TRAF6 levels declined by $82 \pm 3 \%(n=6)$ in U87 cells exposed to a siRNA targeting TLR6 (data not shown).

To investigate any putative role of c-Src and PKC in LPS-induced cell migration, the c-Src inhibitor PP2 (5 $\mu \mathrm{M})$ or both the general PKC inhibitor GF109203X $(1 \mu \mathrm{M})$ and the inhibitor of the classical isoforms, Gö6976 $(5 \mu \mathrm{M})$, were added to U87 cells 30 min prior to LPS addition. PP2 and both PKC inhibitors reduced LPSinduced migration, with GF109203X shown to be the most effective. Conversely, PD 98059 (10 $\mu \mathrm{M})$, a noncompetitive blocker of ERK 1/2 kinase, did not modify U87 cell migration (Fig. 1B). GF109203X, Gö6976 and PD 98059 [39] added alone to U87 cells did not modify cell migration (data not shown).

To investigate if $\mathrm{Ca}^{2+}$ channels mediate LPS-induced cell migration, two selective blockers were used: NNC 55-0396, a mibefradil nonhydrolyzable analogue that blocks T-type $\mathrm{Ca}^{2+}$ channels without L-type $\mathrm{Ca}^{2+}$ channel efficacy [40], and the selective L-type channel blocker nifedipine. Interestingly, NNC 55-0396 (10 $\mu \mathrm{M})$ but not nifedipine $(10 \mu \mathrm{M})$ blocked LPS-induced cell migration NNC 55-0396 or nifedipine alone did not influence cell migration (Fig. 1A and B).

To identify potential transcription factors that mediate U87 cell migration in response to LPS, we used a decoy oligonucleotide approach. As depicted in Fig. 1B, decoy oligonucleotides directed against AP-1, against NF-kB or control oligonucleotides (mutated decoy oligonucleotides) did not modify LPS-mediated cell migration.

In agreement with previous studies $[15,41]$, we observed that LPS $(10 \mathrm{ng} / \mathrm{ml})$ after $24 \mathrm{~h}$ causes a significant increase in U87 cell proliferation.

Knockdown of TLR4 or TRAF6 in U87 cells by a siRNA resulted in a complete abolishment of LPS-mediated This item was downloaded from IRIS Università di Bologna (https://cris.unibo.it/) When citing, please refer to the published version. 
cell proliferation. PP2 and both PKC inhibitors GF109203X and Gö6976 significantly reduced LPS-induced cell proliferation. PD 98059, a non-competitive blocker of ERK kinase, prevented the LPS-induced proliferative effect. The T-channel antagonist NNC 55-0396 $(10 \mu \mathrm{M})$ and the L-channel blocker nifedipine $(10 \mu \mathrm{M})$ did not modify LPS-induced glioblastoma proliferation did not modify cell proliferation when added alone to U87 cells. A decoy oligonucleotide directed against AP-1 or against NF- $\kappa$ B strongly inhibited LPS-mediated cell proliferation. In contrast, control oligonucleotides containing mismatches did not bind AP-1 or NF-kB and were ineffective (Fig. 1C). These results suggest that neither T-type nor L-type calcium channels contribute to modulating LPS-induced cell proliferation, whereas TRAF6, c-Src1 PKC, MAPK or both AP-1 and NF-kB transcription factors mediate LPS-induced cell growth and may represent a target for signaling pathways that need to be investigated in view of any possible cross-talk between N/OFQ and LPS signaling.

To investigate any role of $\mathrm{Ca}^{2+}$ on LPS-promoted on cell migration, U87 cells were stimulated with LPS $(0.1-100 \mathrm{ng} / \mathrm{ml})$, and $\mathrm{Ca}^{2+}$ imaging experiments were performed. To this aim, microfluorometric analysis of intracellular calcium dynamics and concentration was performed in a buffered solution containing $2 \mathrm{mM}$ calcium ions $\left(\left[\mathrm{Ca}^{2+}\right]_{0}\right)$ by ratiometric calcium imaging and analyses of fura-2-loaded cultured U87 cells. The increase in $\left[\mathrm{Ca}^{2+}\right]_{i}$ signals elicited by LPS occurred with an onset of 4-5 $\mathrm{min}$ from solution challenge, reaching the peak amplitude within a few seconds, then returning quickly to the baseline. The viability of responding cells was checked in every experiment by the application of a high $\mathrm{K}^{+}(50 \mathrm{mM})$ external solution (Figure 1G).

LPS-triggered $\mathrm{Ca}^{2+}$ responses were maximum at 10 and $100 \mathrm{ng} / \mathrm{ml}$, with an average $\left[\mathrm{Ca}^{2+}\right]_{\mathrm{i}}$ amplitude equal to $48 \%$ of the baseline value (Fig. 1D). These data agree with Thuringer et al. [15], who studied the role of TLR4 in $\left[\mathrm{Ca}^{2+}\right]_{i}$ elevation promoted by LPS in U87 cells. In all subsequent experiments, U87 cells were stimulated with $10 \mathrm{ng} / \mathrm{ml}$ LPS. Next, we incubated U87 cells in a $\mathrm{Ca}^{2+}$-free solution and found that LPS still induced a $\left[\mathrm{Ca}^{2+}\right]_{\mathrm{i}}$ increase, although the magnitude was smaller than that in the extracellular solution containing $\mathrm{Ca}^{2+}\left(20.7 \pm 4.6 \%\right.$ of the response elicited by $10 \mathrm{ng} / \mathrm{ml}$ LPS in U87 cells incubated in $2 \mathrm{mM} \mathrm{Ca}^{2+}$;

This item was downloaded from IRIS Università di Bologna (https://cris.unibo.it/)

When citing, please refer to the published version. 
$n=30)$; thus, both intracellular $\mathrm{Ca}^{2+}$ release and extracellular $\mathrm{Ca}^{2+}$ entry may contribute to the LPS-induced increase in $\left[\mathrm{Ca}^{2+}\right]_{\mathrm{i}}$. Indeed, LPS has been reported to induce both $\mathrm{Ca}^{2+}$ release from the intracellular stores and $\mathrm{Ca}^{2+}$ entry in U87 cells [15]. Knockdown of TLR4 or TRAF6 resulted in the complete abolishment of the LPS-mediated increase in $\left[\mathrm{Ca}^{2+}\right]_{i}$. The LPS-induced increase in $\left[\mathrm{Ca}^{2+}\right]_{i}$ was significantly reduced by the c-Src inhibitor PP2 (5 $\mu \mathrm{M})$ and NNC 55-0396 (10 $\mu \mathrm{M})$ but not by nifedipine (10 $\mu \mathrm{M})$. (Fig. 1D).

\subsection{Signaling pathways mediating LPS-induced elevation of IL-1 $\beta$ mRNA levels in U87 cells}

TLR4 has been shown to promote glioblastoma growth and malignancy via inducing the production of cytokines, such as IL-1 [7]. In U87 cells, we observed that LPS (10 ng/ml) caused a time-dependent increase in IL-1 $\beta$ mRNA (data not shown) that was significantly increased in comparison with vehicle-treated cells following a $24 \mathrm{~h}$ exposure. RT-PCR analysis showed that LPS elevates IL-1 $\beta$ mRNA levels.

Knockdown of TLR4 in U87 cells by a siRNA resulted in a complete abolishment of the LPS-mediated increase in IL-1 $\beta$ transcripts. PKC inhibitors GF109203X and Gö6976 and the non-competitive blocker of ERK kinase PD 98059 significantly reduced the LPS-induced up-regulation of IL-1ß mRNA. A decoy oligonucleotide directed against AP-1 but not against NF-kB inhibited LPS-mediated IL-1 $\beta$ mRNA levels. In contrast, oligonucleotides containing mismatches, which did not bind AP-1 or NF-kB, respectively, were ineffective. Ttype $\mathrm{Ca}^{2+}$ channel antagonist NNC 55-0396 $(10 \mu \mathrm{M})$ and L-channel blocker nifedipine (10 $\left.\mu \mathrm{M}\right)$ did not modify LPS-induced IL-1 $\beta$ transcription (Fig. 1E). Taken together, these data suggest that LPS-stimulated U87 cells requires PKC and ERK 1/2 activation and involve the AP-1 transcription factor.

3.3. N/OFQ counteracts LPS-induced migration, proliferation and increase of IL-1 $\beta$ in U87 cells

Receptor-binding assays carried out using [ $\left.{ }^{125} \mathrm{I}\right]-\mathrm{N} / \mathrm{OFQ}$, as described under Materials and Methods, This item was downloaded from IRIS Università di Bologna (https://cris.unibo.it/)

When citing, please refer to the published version. 
ascertained that NOP receptors were expressed in U87 cell membranes ( $B_{\max }=213 \pm 12.5 \mathrm{fmol} / \mathrm{mg}$ protein; $\left.K_{d}=0.97 \pm 0.25 ; n=12\right)$.

To evaluate any influence of N/OFQ on LPS-induced migration, we used a wound-healing assay. As shown in Fig. $2 \mathrm{~A}$ and $2 \mathrm{~B}, \mathrm{~N} / \mathrm{OFQ}(1 \mu \mathrm{g} / \mathrm{ml})$ significantly prevented LPS $(10 \mathrm{ng} / \mathrm{ml})$-stimulated cell migration whereas it was ineffective when added alone. In preliminary experiments, we ascertained that N/OFQ (1 nM-10 $\mu \mathrm{M})$ elicited a concentration-dependent blockade of LPS-mediated cell migration, with a maximal effect at 1 and $10 \mu \mathrm{M}$ (data not shown); the concentration of $1 \mu \mathrm{M}$ was chosen according to the experiments described in the subsection 3.1. This inhibitory effect was prevented by the NOPr antagonist [Nphe1]N/OFQ(1-13) $\mathrm{NH}_{2}(10$ $\mu \mathrm{M})$.

The application of N/OFQ in U87 cells pretreated with NNC 55-0396 failed to produce any further inhibition, as N/OFQ may induce inhibition of cell migration through a different mechanism. NOPr is coupled to signaling pathways dependent on pertussis toxin (PTX) sensitive $\mathrm{G \alpha}_{\mathrm{i} / \mathrm{o}}$ protein and $\beta$-arrestin 2 activation [42]; interestingly, $\beta$-arrestin 2 may form a complex with cytoplasmatic proteins that prevent LPS-mediated downstream events $[43,44]$. PTX pretreatment $(100 \mathrm{ng} / \mathrm{ml} ; 18 \mathrm{~h}$ in advance) did not influence N/OFQmediated inhibition of LPS-induced cell migration. On the contrary, using a siRNA directed against $\beta$-arrestin 2, we investigated the influence of this cytoplasmic protein in mediating the signaling from the activated NOPr to LPS-induced cytoplasmatic events. In agreement with Spartà et al. [45], cell transfection with $20 \mu \mathrm{g}$ of siRNA for $\beta$-arrestin 2 effectively and specifically reduced its expression by approximately $80 \%$ (Fig. 2C). After silencing $\beta$-arrestin 2, the N/OFQ-mediated inhibition of LPS-induced cell migration was abolished (Fig. $2 \mathrm{~A}$ and $2 \mathrm{~B})$.

Taken together, these results suggest that $\beta$-arrestin 2 but not the subunit $\mathrm{G \alpha}_{\mathrm{i} / \mathrm{o}}$ of NOPr not T-type nor L-type $\mathrm{Ca}^{2+}$ channels contribute to modulate N/OFQ-induced inhibition of LPS-induced cell migration.

LPS $(10 \mathrm{ng} / \mathrm{ml})$ after $24 \mathrm{~h}$ causes a significant increase in U87 cell proliferation. $\beta$-arrestin 2 , but not PTX This item was downloaded from IRIS Università di Bologna (https://cris.unibo.it/) When citing, please refer to the published version. 
(100 ng/ml) or Ca ${ }^{2+}$ channel blockers NNC 55-0396 and nifedipine, contributes to influencing N/OFQ mediated blockade of LPS-induced cell proliferation. N/OFQ by itself does not influence cell proliferation (Fig. 2D).

N/OFQ counteracts LPS-induced elevation of IL-1 $\beta$ mRNA levels: this effect is sensitive to the administration of the NOPr antagonist [Nphe1]N/OFQ(1-13)NH $(10 \mu \mathrm{M})$ added 5 min prior to N/OFQ or to knockdown of $\beta$-arrestin 2 whereas is not influenced by the T-type $\mathrm{Ca}^{2+}$ blocker NNC 55-0396 (Fig. 2E).

\subsection{N/OFQ and NNC 55-0396 induce apoptotic cell death in U87 cells}

Valerie et al. [19] have previously reported that mibefradil, a blocker of T-type $\mathrm{Ca}^{2+}$ channels, increases apoptosis in several glioblastoma cell lines, including U87 cells. In agreement with these data, we report that both N/OFQ $(1 \mu \mathrm{M})$ and NNC 55-0396 (10 $\mu \mathrm{M})$ promote U87 cell apoptosis. N/OFQ occluded the apoptotic effect induced by NNC 55-0396, whereas LPS did not elicit any apoptotic effect. NOP receptor antagonist [Nphe1]N(OFQ(1-13) $\mathrm{NH}_{2}(10 \mu \mathrm{M})$ blocks N/OFQ-induced apoptosis. Cell apoptosis was measured by annexin V/PI staining (Fig. 3A) or by caspase 3/7 activity (Fig. 3B). By administering a siRNA directed against $\beta$-arrestin 2, no significant N/OFQ-mediated cell apoptosis was observed, whereas a control siRNA was ineffective (data not shown).

\subsection{N/OFQ counteracts LPS-induced $\left[\mathrm{Ca}^{2+}\right]_{i}$ increase in U87 cells via $\beta$-arrestin 2}

The increase in $\left[\mathrm{Ca}^{2+}\right]_{i}$ promoted by LPS $(10 \mathrm{ng} / \mathrm{ml})$ is potently reduced in the presence of N/OFQ $(1 \mu \mathrm{M})$, an effect prevented by the NOPr antagonist [Nphe1]N/OFQ(1-13) $\mathrm{NH}_{2}(10 \mu \mathrm{M})$ added 5 min prior to N/OFQ. PTX (100 ng/ml; $18 \mathrm{~h}$ in advance) does not counteract N/OFQ-mediated antagonism of LPS-induced [Ca $\left.{ }^{2+}\right]_{\mathrm{i}}$ whereas knockdown of $\beta$-arrestin 2 by a siRNA resulted in a complete abolishment of N/OFQ blockade of LPS-

This item was downloaded from IRIS Università di Bologna (https://cris.unibo.it/)

When citing, please refer to the published version. 
mediated cell proliferation. N/OFQ or [Nphe1]N/OFQ(1-13) $\mathrm{NH}_{2}$ alone do not influence $\left[\mathrm{Ca}^{2+}\right]_{\mathrm{i}}$ (Fig. 4).

\subsection{N/OFQ counteracts the LPS-induced phosphorylation of PKC and ERK in U87 cells}

To elucidate any contribution of PKC- and ERK-dependent signaling pathways in mediating any N/OFQ cross-talk with LPS, phosphorylated PKC and ERK were examined by western blot analysis. In preliminary experiments, we ascertained that phosphorylation of PKC and ERK was maximally elevated by LPS (10 ng/ml) or N/OFQ $(1 \mu \mathrm{M}) 15$ min and 60 min after treatment, respectively; neither LPS nor N/OFQ altered the total content of PKC or ERK 1/2 (data not shown). Exposure to N/OFQ (1 $\mu \mathrm{M})$ significantly antagonized LPS-induced phosphorylation of PKC and ERK (Fig. 5). The specificity of N/OFQ acting at the NOPr was confirmed by utilizing the NOP receptor antagonist [Nphe1]N/OFQ(1-13) $\mathrm{NH}_{2}(10 \mu \mathrm{M})$ (data not shown).

\subsection{N/OFQ inhibits the LPS-mediated transcriptional activation of NF-kB and AP-1 reporter genes}

The ability of N/OFQ to inhibit LPS-mediated NF-kB or AP-1 transcriptional activity was determined by a dual-luciferase reporter assay. U87 cells were transfected and treated as described under "Materials and Methods". LPS (10 ng/ml) increased NF-kB transcriptional activity by 3.5 -fold $2 \mathrm{~h}$ after exposure and AP-1 transcriptional activity by 1.8 -fold $6 \mathrm{~h}$ after treatment. Luciferase activity was significantly prevented by $1 \mu \mathrm{M}$ N/OFQ. This peptide, when added alone to cells, did not influence luciferase activity (Fig. 6).

LPS-induced luciferase activity was abolished in U87 cells treated with a decoy oligonucleotide direct against NF-kB and transfected with a reporter plasmid containing the DNA-binding motif of this transcription factor; on the contrary, a mutated oligonucleotide was not effective (Fig. 6A). Similarly, luciferase activity

induced by LPS in cells transfected with a reporter plasmid containing the AP-1 binding sequence, is blocked

This item was downloaded from IRIS Università di Bologna (https://cris.unibo.it/)

When citing, please refer to the published version. 
by a decoy oligonucleotide directed against AP-1 but not by a mutated oligonucleotide (Fig. 6B).

3.8. LPS induces down-regulation of NOPr transcripts and of the density of NOPr binding sites in U87 cells

To further explore any functional cross-talk between NOPr and TLR4, we investigated the effects of TLR4 activation upon NOPr expression. LPS $(10 \mathrm{ng} / \mathrm{ml})$ added to U87 cells for $24 \mathrm{~h}$ caused a significant reduction in steady-state levels of NOP mRNA. A time-course analysis revealed that LPS (10 ng/ml) decreased NOPr mRNA levels by 30 and $75 \%$ at 12 and $24 \mathrm{~h}$, respectively (Fig. 7A). In cells exposed for $24 \mathrm{~h}$ to LPS (0.1-10 ng/ml), a concentration-dependent effect was observed (data not shown). Knockdown of TLR4 in U87 cells resulted in a complete abolishment of LPS-mediated NOPr down-regulation. To better define the mechanism by which LPS may act, the transcriptional inhibitor actinomycin D was employed. Challenge of U87 cells with actinomycin $\mathrm{D}(1 \mu \mathrm{g} / \mathrm{ml} ; 24 \mathrm{~h})$ did not modify NOPr mRNA, whereas LPS-induced reduction of NOPr transcripts was blocked by actinomycin D, indicating that ongoing transcription is required for LPS-induced repression of NOPr (Fig. 7A). As reported previously, LPS may activate distinct groups of cytoplasmatic kinases, including ERK 1/2, PI3K, PKC and p38 mitogen-activated protein kinase [15], via TLR4. Pretreatment with PD $98059(10 \mu \mathrm{M})$, which efficiently eliminates ERK 1/2 signaling [39], did not affect LPS-induced NOPr mRNA down-regulation. Furthermore, this effect was not influenced by the phosphatidylinositol 3-kinase (PI 3-kinase) inhibitor LY294002 (10 $\mu \mathrm{M})$ or by the PKC inhibitor GF109203X (1 $\mu \mathrm{M})$. Interestingly, the p38MAPK inhibitor SB203580 (2 $\mu \mathrm{M})$ [46] was effective in preventing the LPS-induced down-regulation of NOPr mRNA, thus indicating a specific role for this signaling pathway in regulating NOPr mRNA expression. A decoy oligonucleotide directed against AP-1 strongly inhibited the LPS-mediated NOP receptor mRNA reduction (Fig. 7A), whereas an oligonucleotide containing mismatches, which did not bind this transcription factor, was ineffective (data not shown). Finally, a decoy oligonucleotide directed against NF-kB did not change the

This item was downloaded from IRIS Università di Bologna (https://cris.unibo.it/)

When citing, please refer to the published version. 
LPS-mediated effects on NOPr mRNA levels.

In cell cultures treated with $10 \mathrm{ng} / \mathrm{ml}$ LPS for $72 \mathrm{~h}$ but not for $24 \mathrm{~h}$, a significant decrease in the density of $\mathrm{NOPr}$ (Bmax) in U87 cell membranes was confirmed by saturation binding assays (Fig. 7B). Changes in NOPr density had negligible effects on the Kd (apparent affinity of the radioligand to NOPr) (data not shown).

\subsection{LPS-mediated N/OFQ up-regulation and release does not influence NOPr mRNA down-regulation}

Previous studies have reported that astrocytes produce and secrete N/OFQ, thus pointing to these cells as a source of N/OFQ [26]. Importantly, inflammatory mediators, including LPS and cytokines, modulate both the transcription of N/OFQ mRNA and N/OFQ expression and release $[47,48]$, thus suggesting that N/OFQ, by binding to NOPr expressed in these cells, may act as a paracrine and autocrine modulator to control its own production and secretion and may also down-regulate NOPr [23]. In U87 cells exposed to LPS (10 ng/ml; 6-24 h), a time-dependent increase in the release of ir-N/OFQ in cell culture medium was measured in comparison to cells exposed to the vehicle maintained in cell culture medium containing $10 \%$ fetal bovine serum (Fig. 8A). Furthermore, a significant increase in ir-N/OFQ cellular content was detected $24 \mathrm{~h}$ after LPS exposure (Fig. 8B) Interestingly, LPS-induced NOPr mRNA down-regulation, previously described, was not influenced by the NOPr antagonist [Nphe1]N/OFQ(1-13) $\mathrm{NH}_{2}(10 \mu \mathrm{M})$ when added to the cells 30 min before LPS treatment for $24 \mathrm{~h}$. Furthermore, this NOPr antagonist administered alone did not alter NOPr mRNA levels (Fig. 8C). Taken together, these data indicate that LPS-induced NOPr mRNA down-regulation is not influenced by any relevant paracrine and/or autocrine effect elicited by N/OFQ released by LPS in U87 cells that, if present, could be reduced by a NOPr antagonist.

3.10. Prolonged exposure to LPS abolishes the inhibitory effect of N/OFQ on LPS-induced cell proliferation and

This item was downloaded from IRIS Università di Bologna (https://cris.unibo.it/)

When citing, please refer to the published version. 
increase of IL-1 $\beta$ mRNA transcripts

N/OFQ mediated effects on LPS-induced cell migration, proliferation and IL-1 $\beta$ mRNA transcripts were investigated in U87 cells following a subsequent exposure to LPS; since this agent may promote tolerance of TLR-4-mediated responses [49]. U87 cells were pretreated with $10 \mathrm{ng} / \mathrm{ml}$ LPS for $72 \mathrm{~h}$ and subsequently they were washed thoroughly three times, maintained in fresh cell culture medium and $6 \mathrm{~h}$ later rechallenged with LPS $(10 \mathrm{ng} / \mathrm{ml}$ ) to assay cell migration (after $18 \mathrm{~h}$ ), proliferation and elevation of IL-1 $\beta$ mRNA transcripts (after $24 \mathrm{~h}$ ); alternatively, the cells were maintained in cell culture medium (vehicle). Cell migration was significantly increased in U87 cells treated for $72 \mathrm{~h}$ with LPS and then rechallenged with this agent or maintained with the vehicle alone for $18 \mathrm{~h}$ in comparison to cells treated only with vehicle for $18 \mathrm{~h}$ (basal vehicle). Interestingly, N/OFQ, added with LPS, was not able to counteract this effect (Fig. 9A).

Rechallenge of LPS for $24 \mathrm{~h}$ promoted a significant cell proliferation and increase in IL-1 $\beta$ mRNA levels in comparison with cells treated for $72 \mathrm{~h}$ with LPS and then maintained in the presence of the vehicle. In U87 cells rechallenged with LPS and N/OFQ, this peptide did not prevent the LPS-stimulated cell migration and proliferation or increase in IL-1 $\beta$ mRNA (Fig. 9B and C). In cells treated for $72 \mathrm{~h}$ with LPS and then maintained in the presence of the vehicle for $24 \mathrm{~h}$, cell proliferation and levels of IL-1 $\beta$ mRNA are superimposable to those observed in cells treated with the vehicle for $24 \mathrm{~h}$ (basal vehicle) (Fig. 9B and C). In cell cultures treated with LPS for $72 \mathrm{~h}$ and rechallenged for $24 \mathrm{~h}$, a significant decrease in the density of NOPr was confirmed by saturation binding assays (data not shown).

\section{Discussion}

Fève et al. [22] have carried out a proteomic analysis of GPCRs expressed in human glioblastoma cells. They report that NOPr is in the repertoire of GPCRs significantly expressed in glioblastoma cells, including the U87 cell line, and consider these data as a first step that will require future functional studies to decipher the

This item was downloaded from IRIS Università di Bologna (https://cris.unibo.it/)

When citing, please refer to the published version. 
precise role of this receptor in sustaining the cancerous phenotype.

In the present study, we describe a novel role of the peptide N/OFQ, which by binding to NOPr, is capable of counteracting the cell migration, proliferation and increase in IL-1 $\beta$ mRNA elicited by LPS, via TLR4, in U87 glioblastoma cells. Independent of LPS, N/OFQ induces a significant increase in cell apoptosis.

Glioma overexpress TLRs that seem to be involved in tumor progression and chemotherapy resistance as well as in immune and inflammatory responses [50]. Rhee and Hwang [51] have reported that a low concentration of LPS (20 ng/ml) activates NF- $k B$ and cyclooxygenase-2 expression in a murine macrophagelike cell line transfected with the constitutively active form of TLR4, and Erridge [52] has described that LPS is effective in HEK 293 cells transfected with TLR4 at $10 \mathrm{ng} / \mathrm{ml}$. Thus, even small amounts of LPS are sufficient to induce potent inflammatory responses. In agreement with these studies, we have used a low concentration of LPS $(10 \mathrm{ng} / \mathrm{ml})$, as it may also mimic the activation of TLR4 by endogenous ligands originating from dying cells or the extracellular matrix that may be produced during tumor growth [13]. These molecules include "alarmins", which have been proposed to serve as mediators of inflammation. They may be expressed or released in response to tissue damage [53]. The concentrations of the alarmins HMGB1and myeloidrelated protein 8 , all activators of TLR4, are in the $\mathrm{ng} / \mathrm{ml}$ range [54].

Possible intracellular mechanisms through which N/OFQ antagonizes the above-mentioned LPSmediated effects have been investigated in this study. Furthermore, we have observed that a prolonged exposure of U87 cells to LPS for up to $96 \mathrm{~h}$ down-regulates NOPr expressed in U87 cells and, in parallel, N/OFQ loses its inhibitory activity.

\section{1. $\left[\mathrm{Ca}^{2+}\right]_{i}$ and the cross-talk between NOPr and TLR4}

We prove that in U87 cells, NNC 55-0396, a mibefradil nonhydrolyzable analogue that blocks T-type

This item was downloaded from IRIS Università di Bologna (https://cris.unibo.it/)

When citing, please refer to the published version. 
calcium channels without L-type channel efficacy [40], significantly reduces LPS-mediated cell migration, whereas the L-type calcium channel antagonist nifedipine is not effective. Application of N/OFQ in U87 cells pretreated with NNC 55-0396 fails to produce any further inhibition of cell migration, as this latter compound does not influence may occlude N/OFQ-induced inhibition of LPS-promoted cell migration. Furthermore, both calcium channel antagonists do not influence LPS-mediated U87 cell proliferation or the increase in IL$1 \beta$ mRNA. Finally, N/OFQ administered alone does not modify $\left[\mathrm{Ca}^{2+}\right]_{i}$ of U87 cells.

As a second messenger, $\mathrm{Ca}^{2+}$ is necessary for several cellular responses. In U87 cells, we have observed that LPS arouses a transient increase in $\left[\mathrm{Ca}^{2+}\right]_{i}$ that, at least partially, requires T-type calcium channels. This observation agrees with a recent study carried out in uterine smooth muscle cells, where the increase in $\left[\mathrm{Ca}^{2+}\right]_{\mathrm{i}}$ by LPS is reversed by T-type $\mathrm{Ca}^{2+}$ channel antagonists [55].

U87 cells express all three $\alpha_{1}$ subunits of T-type calcium channels (Cav3.1, Cav 3.2, Cav3.3) [56], and the majority of studies agree with the occurrence of functional T-type calcium channels in glioblastoma cells, where they play a relevant role in cell migration, proliferation and apoptosis [19,57].

Taken together, these data do not support the hypothesis that N/OFQ may influence LPS-induced cell migration directly modulating $\mathrm{Ca}^{2+}$ channels and argue in favor of different signaling pathways activated by N/OFQ.

Valerie et al. [19] have proved that inhibition of T-type channels with mibefradil or down-regulation of T-type channel subunit expression with siRNA leads to an increase in apoptosis of U87 and other glioblastoma cells and sensitizes them to ionizing radiation in vitro. In agreement with this study, we found that NNC 550396 significantly increases apoptosis in U87 cells and that N/OFQ produces a superimposable cell apoptosis. Conversely, LPS does not cause the apoptosis of U87 cells. In agreement with these data, Nagano et al. [58] have reported that LPS $(100 \mathrm{ng} / \mathrm{ml})$ does not influence viability or apoptosis of glial cells. Furthermore, it should be noted that U87 cells, as well as other glioblastoma, are poor sensitive to apoptosis [59]. An This item was downloaded from IRIS Università di Bologna (https://cris.unibo.it/) When citing, please refer to the published version. 
important aspect of the pathogenesis of glioma, in fact, is that malignant transformation results from the sequential accumulation of genetic modifications and altered regulation of several signaling pathways. These aberrations primarily lead to abnormal regulation of two major cellular systems: the growth factor-mediated signaling pathways and the cell cycle that plays a role in the increased cell proliferation, inhibition of apoptosis, invasion and angiogenesis [4]. Crucial questions about the nature of the signaling pathways involved in the N/OFQ-mediated inhibition of T-type channels remain to be further investigated.

\section{2. $\beta$-arrestin 2 contributes to the cross-talk between NOPr and TLR4}

NOPr is coupled to signaling pathways dependent on $\mathrm{G}$ protein and $\beta$-arrestin 2 activation $[42,60]$, with this latter originally discovered for its ability to desensitize $G$ protein-mediated signaling [61]. We have observed that by silencing this versatile adaptor and signaling protein $[16,17]$, the negative crosstalk between NOPr and TLR4 is removed, as N/OFQ is no longer able to block LPS-mediated U87 cell migration, proliferation and increase in IL-1 $\beta$ mRNA. $\beta$-arrestin 2 undergoes dynamic ubiquitination/deubiquitination and is capable of recruiting E3 ubiquitin ligases to other substrates [61]. LPS binding to TLR4 activates the E3 ubiquitin ligase TRAF6 that is important for NF-אB activation [44]. Recently, Madera-Salcedo et al. [43] have reported that in mast cells, morphine binds to a GPCR and activates $\beta$-arrestin 2 that forms a complex with TRAF 6 , thus preventing LPS-mediated ERK 1/2 and NF-KB activation and tumor necrosis factor secretion.

As regards U87 cells, we report that transfection with TRAF6 siRNA blocks LPS-induced cell migration, proliferation and increase in $\left[\mathrm{Ca}^{2+}\right]_{i}$, suggesting that this adaptor protein may participate in the blockade of LPS signaling promoted by N/OFQ through activation of $\beta$-arrestin 2 .

The contribution of $\beta$-arrestin 2 to NOPr activation and internalization has been reported $[23,24]$. Future studies are necessary for further investigation of any relationship between NOPr- and TLR4- promoted $\beta$ -

This item was downloaded from IRIS Università di Bologna (https://cris.unibo.it/)

When citing, please refer to the published version. 
arrestin 2 ubiquitination and deubiquitination.

Finally, LPS-induced cell migration is not dependent on nuclear transcription factors NF-KB and AP-1.

\subsection{N/OFQ counteracts LPS-induced signaling activation}

In U87 cells, LPS induces cell migration, proliferation and an increase in IL-1 $\beta$ mRNA, which are prevented by the PKC inhibitor GF $109203 \mathrm{X}$ that is capable of blocking the activation of classic and novel PKC isoforms, while Go6976, a blocker of PKC $\alpha$ and PKC $\beta 1$, is only partially effective, thus indicating that several PKC isoforms are preferentially activated by LPS [39]. PKC activation is one of the earliest events in a cascade that controls a variety of cellular responses, and several PKC isoforms contribute to cell glioma proliferation, migration and survival [62]. In agreement with previous studies, we ascertained that LPS-induced cell migration and proliferation and elevation in $\left[\mathrm{Ca}^{2+}\right]_{i}$ requires a signaling pathway that includes the kinase $\mathrm{c}^{-}$ Src, that may connect TRAF6 to downstream components including PKC and ERK $1 / 2$ kinases [15].

LPS triggers cell proliferation but not migration through a pathway that is also sensitive to the ERK $1 / 2$ inhibitor PD 98059. LPS and N/OFQ alone induce significant phosphorylation of PKC and ERK 1/2; however, LPS-promoted PKC and ERK 1/2 phosphorylation are blocked by N/OFQ.

It is known that N/OFQ by itself can activate PKC via NOPr and that this activation may involve the phospholipase $\mathrm{C} / \mathrm{Ca}^{2+}$ system and may cause ERK $1 / 2$ phosphorylation [23]; however, these signaling pathways do not contribute to migration and proliferation in U87 cells, as N/OFQ alone does not produce any change of these parameters. We retain that N/OFQ may counteract LPS-mediated signaling via $\beta$-arrestin 2 and it does not require PKC and ERK 1/2 signaling pathways. In agreement with this hypothesis, Thuringer et al. [15] have reported that LPS via TLR4 promotes PKC activation and hydrolysis of phosphatidylinositol 4,5-biphosphate into Inositol $(1,4,5) \mathrm{P}_{3}$ and 1,2-diacylglycerol in U87 cells. Inositol(1,4,5) $\mathrm{P}_{3}$ releases

This item was downloaded from IRIS Università di Bologna (https://cris.unibo.it/)

When citing, please refer to the published version. 
intracellular $\mathrm{Ca}^{2+}$, which is followed, as described previously, by $\mathrm{Ca}^{2+}$ influx from extracellular spaces. PKC isoenzymes, at least in part through $\left[\mathrm{Ca}^{2+}\right]_{\text {, }}$, regulate the phosphorylation of ERK $1 / 2$ that in turn activates transcription factors such as NF-kB and AP-1. These authors proposed that the cooperation of these signaling messengers may promote cell proliferation, as well as the expression and release of inflammatory mediators.

TLR4 modulates different signaling pathways influencing cell proliferation that require transcription factors NF- $k B$ [11] and AP-1 [12]; both contribute to regulating the expression of a large number of genes involved in the pathogenesis and/or progression of glioblastoma.

We found that in U87 cells, as evidenced by gene reporter assays, N/OFQ prevents transcriptional activation modulated by both transcription factors. Furthermore, decoy oligonucleotides specific for these proteins block LPS-induced cell proliferation but not migration. Interestingly, only a decoy oligonucleotide towards AP-1 blocked the LPS-induced increase in IL-1 $\beta$ mRNA.

Evidence that the transcription factor NF- $\kappa$ B plays a role in the control of oncogenesis, tumor progression and chemotherapy resistance of diverse types of malignances, including glioma, has been provided [11]. AP1 proteins are transcription factors that belong to the Jun, Fos and closely related activating factor (ATF) families. They are involved in numerous cellular process including apoptosis and growth promotion [12]. In this perspective, inhibition of NF-kB and AP-1 signaling mechanisms may represent a rational target in the development of novel therapeutic approaches against carcinogenesis [63, 64].

As mentioned before, N/OFQ blocks the LPS-mediated increase in IL-1 $\beta$ mRNA. Recently, the importance of the tumor microenvironment, including glial and neuronal cells, in the production of inflammatory mediators that may contribute to glioma progression has been noted as a crucial event in carcinogenesis and tumor progression $[7,8]$. In this context, chronic overexpression of IL-1 $\beta$ has been considered a tumorpromoting condition, arguing in favor of its inhibition for tumor prevention or therapy [65]. Tarassishin et al. [66] have described that IL-1 $\beta$ production by glioblastoma cells may confer upon them a mesenchymal This item was downloaded from IRIS Università di Bologna (https://cris.unibo.it/) When citing, please refer to the published version. 
phenotype, including increased cell migration, a specific gene signature and proinflammatory signaling.

\subsection{LPS down-regulates NOPr in U87 cells}

LPS treatment causes a concentration-dependent reduction of NOPr mRNA in U87 cells exposed to this agent for $24 \mathrm{~h}$ and a noteworthy reduction of NOPr expressed in cells exposed to LPS for $72 \mathrm{~h}$.

We used the transcriptional inhibitor actinomycin D to better define the mechanism by which LPS downregulates NOP mRNA. This agent is capable of preventing the effect of LPS, thus indicating that it may require a transcriptional repressor(s) to reduce NOP mRNA levels. LPS-induced NOP mRNA down-regulation is blocked by the p38MAPK inhibitor SB203580 [46] and by a decoy oligonucleotide directed against AP-1. Thus, these signaling pathways that, as previously described, contribute to oncogenic transformation and progression may regulate NOPr mRNA by LPS.

Interestingly, LPS induces a significant increase of N/OFQ in U87 cell extracts and in cell culture medium. This latter effect is maintained in cells treated with the NOP antagonist [Nphe1]N/OFQ(1-13) $\mathrm{NH}_{2}$. Therefore, it could be hypothesized that any possible autocrine/paracrine effect elicited by the released endogenous N/OFQ on LPS-induced NOP mRNA reduction could be ruled out.

NOPr and N/OFQ have been detected in human peripheral blood cells $[67,68]$, and Zhang et al. [47] have observed that NOPr and pre-N/OFQ mRNA are modulated differently by inflammatory cytokines in human peripheral blood cells. LPS strongly suppresses NOPr mRNA, whereas the effects on pre-N/OFQ mRNA are minor. These findings further confirm that LPS may down-regulate NOPr mRNA, whereas the data on LPSinduced pre-N/OFQ mRNA and immunoreactive N/OFQ deserve to be further explored.

Buzas et al. [26] have described that LPS and proinflammatory cytokines elevate pre-N/OFQ mRNA and This item was downloaded from IRIS Università di Bologna (https://cris.unibo.it/) 
the content of immunoreactive N/OFQ in astrocytes.

Previous findings have suggested that NOPr and N/OFQ are expressed in the human central nervous system, as well as in immune cells, and may contribute to mediating immune responses with possible involvement of the brain-immune axis [69]. In vitro and in vivo studies support the evidence that NOPr and N/OFQ are involved in systemic inflammatory reactions and sepsis [70]. Thus, it could be suggested that there is a regulatory loop between the NOPr and cytokines. NOPr mRNA expression was found to be increased in cancer or septic patients, with highest levels in end-stage cancer patients. In contrast, pre-N/OFQ was decreased.

Forshammar et al. [71] have reported that in astrocytes a prolonged exposure to LPS evokes an elevation of $\left[\mathrm{Ca}^{2+}\right]_{i}$ transients expressed as oscillations together with a rearrangement of actin filaments. As regards U87 cells, we have observed that a significant increase in the amplitude, duration and number of peaks of $\left[\mathrm{Ca}^{2+}\right]_{\mathrm{i}}$ is evident in U87 cells exposed to LPS for $72 \mathrm{~h}$ in comparison with cells acutely exposed to this agent (data not shown). These events may contribute to the significant cell migration observed in U87 cells rechallenged with LPS or with the vehicle. Furthermore, LPS rechallenge abolishes the inhibitory effects of N/OFQ on LPS-induced cell proliferation and increase in IL-1 $\beta$ mRNA as consequence of the down-regulation of NOPr observed in U87 cells treated with LPS up to $96 \mathrm{~h}$.

Prolonged exposure to LPS may induce tolerance that results in reduced inflammatory cytokine response [72] by reprogramming the host response, thus preventing overstimulation from the continuous presence of danger signals. It has been proposed that changes of TLR4 downstream signaling may contribute to LPS-induced tolerance [49]; however, tolerance to LPS-promoted cell migration, proliferation, IL-1 $\beta$ mRNA and NOPr down-regulation was not observed in U87 glioblastoma cells. A prolonged occurrence of LPS can up-regulate several miRNAs including miR146a [73] and miR-155 [49]; miR-146a may inhibit proteins involved in the signaling pathways

This item was downloaded from IRIS Università di Bologna (https://cris.unibo.it/)

When citing, please refer to the published version. 
activated by LPS [74]. Interestingly, miRNA-146a is down regulated in glioblastoma; thus, any inhibitory role played by this miRNA on TLR4-activated downstream signaling could be inadequate in these cells [75]. Conversely, miR-155 may play an oncogenic pro-inflammatory action as is upregulated in glioma; by promoting cell migration and proliferation it may counteract LPS-mediated tolerance to cell migration, proliferation and IL-1 $\beta$ mRNA increase [76].

Glioma cells are not the only cells that express TLRs as tumor microenvironment contains resident and infiltrating immune cells that may contribute to tumor progression and have not been extensively studied [5]. It could be hypothesized that DAMPs produced by necrotic cells, a hallmark of tumor progression, may accumulate in the tumor microenvironment and contribute to NOPr downregulation by activating TLR4 for a prolonged period of time; thus, the inhibitory effect of N/OFQ on LPS-mediated cell migration, proliferation and IL-1 $\beta$ mRNA transcripts could be lost. Future research should focus on the complex role played by TLRs, and their endogenous ligands DAMPs, as mediators of cellular signaling pathways that may favor or antagonize tumor progression [77].

G-protein coupled receptors have gained interest in anti-tumor drug discovery due to the prominent role that they can play, directly or indirectly, though transactivation of other receptors in glioma, causing proliferation, migration/metastasis, angiogenesis and metabolism [78]. To the best of our knowledge, this is the first report showing that N/OFQ may block LPS-induced glioblastoma cell proliferation and migration and may influence the inflammatory response mediated by cytokines. Furthermore, independent of LPS, N/OFQ increases apoptosis. These data are in agreement with evidence indicating that anti-inflammatory-based therapies could prove to be useful tools in combating glioblastoma. Future studies are necessary for a more

This item was downloaded from IRIS Università di Bologna (https://cris.unibo.it/)

When citing, please refer to the published version. 
in-depth exploration of any functional cross-talk between TLR4 and NOPr in glioblastoma cells.

\section{Author contributions}

$A B$ and $M B$ planned and designed the experiments, carried out the experiments, analyzed the data, contributed to write the manuscript and revised it critically for important intellectual content; GV, FF, SL and MC designed and carried out some experiments, analyzed the data and contributed to write the manuscript; SS planned and designed the experiments, supervised the project and wrote the manuscript.

\section{Conflict of interest}

The authors confirm that they have no conflict of interest to declare for this publication.

\section{Acknowledgments}

This work was supported by grants from the University of Bologna FARB FFBO 125290 and RFO 2014 and from MIUR (PRIN 2010).

\section{References}

[1] I. Jovčevska, N. Kočevar, R. Komel, Glioma and glioblastoma - how much do we (not) know? Mol. Clin. Oncol. 1 (2013) 935-941.

[2] C.L. Gladson, R.A. Prayson, W.M. Liu, The pathobiology of glioma tumors, Annu. Rev. 
Pathol. 5 (2010) 33-50. doi: 10.1146/annurev-pathol-121808-102109.

[3] I. Veliz, Y. Loo, O. Castillo, N. Karachaliou, O. Nigro, R. Rosell, Advances and challenges in the molecular biology and treatment of glioblastoma - is there any hope for the future? Ann. Transl. Med. 3 (2015) 7. doi: 10.3978/j.issn.2305-5839.2014.10.06.

[4] A.L. Cohen, H. Colman, Glioma biology and molecular markers, Cancer. Treat. Res. 163 (2015) 15-30. doi: 10.1007/978-3-319-12048-5_2.

[5] N.A. Charles, E.C. Holland, R. Gilbertson, R. Glass, H. Kettenmann, The brain tumor microenvironment, Glia 60 (2012) 502-514.

[6] J.L. Sowers, K.M. Johnson, C. Conrad, J.T. Patterson, L.C. Sowers, The role of inflammation in brain cancer, Adv. Exp. Med. Biol. 816 (2014) 75-105. doi: 10.1007/978-3-0348-08378_4.

[7] Y.T. Yeung, K.L. McDonald, T. Grewal, L. Munoz, Interleukins in glioblastoma pathophysiology: implications for therapy, Br. J. Pharmacol. 168 (2013) 591-606. doi: 10.1111/bph.12008.

[8] C.A. Dinarello, Why not treat human cancer with interleukin-1 blockade? Cancer Metastasis Rev. 29 (2010) 317-329. doi: 10.1007/s10555-010-9229-0.

[9] L. Zitvogel, O. Kepp, L. Galluzzi, G. Kroemer, Inflammasomes in carcinogenesis and anticancer immune responses, Nat. Immunol. 13 (2012) 343-351. doi:10.1038/ni.2224.

[10] E. Sen, Targeting inflammation-induced transcription factor activation: an open frontier for glioma therapy. Drug Discov. Today 16 (2011) 1044-1051. doi:

10.1016/j.drudis.2011.09.003.

[11] L. Nogueira, P. Ruiz-Ontañon, A. Vazquez-Barquero, F. Moris, J.L. Fernandez-Luna, The NF- $k$ B pathway: a therapeutic target in glioblastoma, Oncotarget 2 (2011) 646-653.

[12] M. Gozdecka, W. Breitwieser, The roles of ATF2 (activating transcription factor 2) in This item was downloaded from IRIS Università di Bologna (https://cris.unibo.it/) 
tumorigenesis, Biochem. Soc. Trans. 40 (2012) 230-234. doi: 10.1016/j.celrep.2014.10.043.

[13] S. Gaikwad, D. Patel, R. Agrawal-Rajput, CD40 Negatively Regulates ATP-TLR4-Activated Inflammasome in Microglia, Cell Mol. Neurobiol. 2016 Mar 10. [Epub ahead of print] PubMed PMID: 26961545. doi: 10.1038/icb.2013.58.

[14] M. Escamilla-Tilch, G. Filio-Rodríguez, R. García-Rocha, I. Mancilla-Herrera, N.A. Mitchison, J.A. Ruiz-Pacheco, F.J. Sánchez-García, D. Sandoval-Borrego, E.A. VázquezSánchez, The interplay between pathogen-associated and danger-associated molecular patterns: an inflammatory code in cancer? Immunol. Cell Biol. 91 (2013) 601-610. doi: 10.1038/icb.2013.58.

[15] D. Thuringer, A. Hammann, N. Benikhlef, E. Fourmaux, A. Bouchot, G. Wettstein, E. Solary, C. Garrido, Transactivation of the epidermal growth factor receptor by heat shock protein 90 via Toll-like receptor 4 contributes to the migration of glioblastoma cells, J. Biol. Chem. 286 (2011) 3418-3428. doi: 10.1074/jbc.M110.154823.

[16] T. Ve, N.J. Gay, A. Mansell, B. Kobe, S. Kellie, Adaptors in toll-like receptor signaling and their potential as therapeutic targets. Curr Drug Targets 13 (2012) 1360-1374.

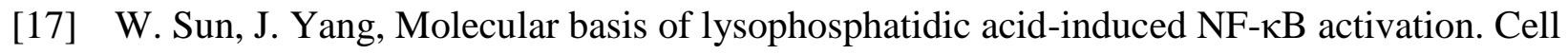
Signal. 22 (2010) 1799-1803. doi:10.1016/j.cellsig.2010.05.007.

[18] T.A. Stewart, K.T. Yapa, G.R. Monteith, Altered calcium signaling in cancer cells, Biochim. Biophys. Acta 1848 (2015) 2502-2511. doi:10.1016/j.bbamem.2014.08.016.

[19] N.C. Valerie, B. Dziegielewska, A.S. Hosing, E. Augustin, L.S. Gray, D.L. Brautigan, J.M. Larner, J. Dziegielewski, Inhibition of T-type calcium channels disrupts Akt signaling and promotes apoptosis in glioblastoma cells, Biochem. Pharmacol. 85 (2013) 888-897. doi: 10.1016/j.bcp.2012.12.017.

[20] M. O'Hayre, M.S. Degese, J.S. Gutkind, Novel insights into G protein and G protein-coupled This item was downloaded from IRIS Università di Bologna (https://cris.unibo.it/) 
receptor signaling in cancer, Curr. Opin. Cell Biol. 27 (2014) 126-135. doi: 10.1016/j.ceb.2014.01.005.

[21] C. Friesen, I. Hormann, M. Roscher, I. Fichtner, A. Alt, R. Hilger, K.M. Debatin, E. Miltner, Opioid receptor activation triggering downregulation of cAMP improves effectiveness of anti-cancer drugs in tretment of glioblastoma, Cell Cycle 13 (2014) 1560-1570. doi: 10.4161/cc.28493.

[22] M. Fève, J.M. Saliou, M. Zeniou, S. Lennon, C. Carapito, J. Dong, A. Van Dorsselaer, M.P. Junier, H. Chneiweiss, S. Cianférani, J. Haiech, M.C. Kilhoffer, Comparative expression study of the endo-G protein coupled receptor (GPCR) repertoire in human glioblastoma cancer stem-like cells, U87-MG cells and non malignant cells of neural origin unveils new potential therapeutic targets, PLoS One. 9 (2014) e91519. doi:10.1371/journal.pone.0091519.

[23] C.L. Donica, H.O. Awwad, D.R. Thakker, K.M. Standifer, Cellular mechanisms of nociceptin/orphanin FQ (N/OFQ) peptide (NOP) receptor regulation and heterologous regulation by N/OFQ, Mol. Pharmacol. 83 (2013) 907-918. doi:10.1124/mol.112.084632.

[24] M. Baiula, A. Bedini, S.M. Spampinato, Role of nociceptin/orphanin FQ in thermoregulation, Neuropeptides 50 (2015) 51-56. doi:10.1016/j.npep.2015.03.005.

[25] X. Fu, Z.H. Zhu, Y.Q. Wang, G.C. Wu, Regulation of proinflammatory cytokines gene expression by nociceptin/orphanin FQ in the spinal cord and the cultured astrocytes, Neuroscience 144 (2007) 275-285.

[26] B. Buzas, J. Rosenberger, K.W. Kim, B.M. Cox, Inflammatory mediators increase the expression of nociceptin/orphanin FQ in rat astrocytes in culture, Glia 39 (2002) 237-246.

[27] J.J. Seeley, S. Ghosh, Molecular mechanisms of innate memory and tolerance to LPS, J. Leukoc. Biol. 101 (2017) 107-119. doi: 10.1189/jlb.3MR0316-118RR.

[28] T. Gebäck, M.M. Schulz, P. Koumoutsakos, M. Detmar, TScratch: a novel and simple This item was downloaded from IRIS Università di Bologna (https://cris.unibo.it/) 
software tool for automated analysis of monolayer wound healing assays, Biotechniques 46 (2009) 265-274. doi: 10.2144/000113083.

[29] R. Di Toro, M. Baiula, S. Spampinato, Expression of the repressor element-1 silencing transcription factor (REST) is influenced by insulin-like growth factor-I in differentiating human neuroblastoma cells, Eur. J. Neurosci. 21 (2005) 46-58.

[30] A. Bedini, M. Baiula, S. Spampinato, Transcriptional activation of human mu-opioid receptor gene by insulin-like growth factor-I in neuronal cells is modulated by the transcription factor REST, J. Neurochem. 105 (2008) 2166-2178. doi: 10.1111/j.1471-4159.2008.05303.x.

[31] J. Winer, C.K. Jung, I. Shackel, P.M. Williams, Development and validation of real-time quantitative reverse transcriptase-polymerase chain reaction for monitoring gene expression in cardiac myocytes in vitro, Anal. Biochem. 270 (1999) 41-49.

[32] S. Yang, P. Wang, X. Wang, K. Zhang, X. Zhang, Q. Liu, Efficacy of combined therapy with paclitaxel and low-level ultrasound in human chronic myelogenous leukemia cell line K562, J. Drug Target 21 (2013) 874-884. doi:10.3109/1061186X.2013.830309.

[33] V. Benfenati, M. Caprini, M. Dovizio, M.N. Mylonakou, S. Ferroni, O.P. Ottersen, M. Amiry-Moghaddam, An aquaporin-4/transient receptor potential vanilloid 4 (AQP4/TRPV4) complex is essential for cell-volume control in astrocytes, Proc. Natl. Acad. Sci. USA 108 (2011) 2563-2568. doi: 10.1073/pnas.1012867108.

[34] G. Grynkiewicz, M. Poenie, R.Y. Tsien, A new generation of $\mathrm{Ca}^{2+}$ indicators with greatly improved fluorescence properties, J. Biol. Chem. 260 (1985) 3440-3450.

[35] J. Kraus, C. Börner, E. Giannini, V. Höllt, The role of nuclear factor kappaB in tumor necrosis factor-regulated transcription of the human mu-opioid receptor gene, Mol. Pharmacol. 64 (2003) 876-884.

[36] C. Börner, A. Bedini, V. Höllt, J. Kraus, Analysis of promoter regions regulating basal and This item was downloaded from IRIS Università di Bologna (https://cris.unibo.it/) 
interleukin-4-inducible expression of the human CB1 receptor gene in T lymphocytes, Mol. Pharmacol. 73 (2008) 1013-1019.

[37] R. De Marco, A. Bedini, S. Spampinato, L. Cavina, E. Pirazzoli, L. Gentilucci, Versatile Picklocks To Access All Opioid Receptors: Tuning the Selectivity and Functional Profile of the Cyclotetrapeptide c[Phe-d-Pro-Phe-Trp] (CJ-15,208), J. Med. Chem. 59 (2016) 92559261.

[38] C. Petrella, C. Giuli, M. Broccardo, H. Eutamene, C. Cartier, M. Leveque, A. Bedini, S. Spampinato, L. Bueno, V. Theodorou, G. Improta, S. Agostini, Protective and worsening peripheral nociceptin/orphanin FQ receptor-mediated effect in a rat model of experimental colitis, Pharmacol. Res. 70 (2013) 72-79. doi:10.1016/j.phrs.2013.01.004.

[39] L.C. Chang, J.P. Wang, Signal transduction pathways for activation of extracellular signalregulated kinase by arachidonic acid in rat neutrophils, J. Leukoc. Biol. 69 (2001) 659-665.

[40] L. Huang, B.M. Keyser, T.M. Tagmose, J.B. Hansen, J.T. Taylor, H. Zhuang, M. Zhang, D.S. Ragsdale, M. Li, NNC 55-0396[(1S,2S)-2-(2-(N-[(3-benzimidazol-2-yl)propyl]-Nmethylamino)ethyl)-6-fluoro-1,2,3,4-tetrahydro-1-isopropyl-2-naphtyl cyclopropanecarboxylate dihydrochloride]: a new selective inhibitor of T-type calcium channel, J. Pharmacol. Exp. Ther. 309 (2004) 193-199.

[41] A. Campbell, E.Y. Yang, M. Tsai-Turton, S.C. Bondy, Pro-inflammatory effects of aluminum in human glioblastoma cells, Brain Res. 933 (2002) 60-65.

[42] S. Spampinato, R. Di Toro, A.R. Qasem, Nociceptin-induced internalization of the ORL1 receptor in human neuroblastoma cells, Neuroreport 12 (2001) 3159-3163.

[43] I.K. Madera-Salcedo, S.L. Cruz, C. Gonzalez-Espinosa, Morphine prevents lipopolysaccharide-induced TNF secretion in mast cells blocking I $\mathrm{B}$ kinase activation and SNAP-23 phosphorylation: correlation with the formation of a $\beta$-arrestin/TRAF6 complex, J.

This item was downloaded from IRIS Università di Bologna (https://cris.unibo.it/)

When citing, please refer to the published version. 
Immunol. 191 (2013) 3400-3409. doi:10.4049/jimmunol.1202658.

[44] P.Y. Jean-Charles, L. Zhang, J.H. Wu, S.O. Han, L. Brian, N.J. Freedman, S.K. Shenoy, Ubiquitin specific Protease 20 Regulates the Reciprocal Functions of $\beta$-Arrestin2 in Toll-like Receptor 4-promoted Nuclear Factor kB (NF-kB) Activation, J. Biol. Chem. 291 (2016) 7450-7464. doi: 10.1074/jbc.M115.687129

[45] A. Spartà, M. Baiula, G. Campbell, S. Spampinato, beta-Arrestin 2-mediated heterologous desensitization of IGF-IR by prolonged exposure of SH-SY5Y neuroblastoma cells to a mu opioid agonist, FEBS Lett. 584 (2010) 3580-3586. doi: 10.1016/j.febslet.2010.07.025.

[46] J.C. Lee, S. Kassis, S. Kumar, A. Badger, J.L. Adams, p38 mitogen-activated protein kinase inhibitors--mechanisms and therapeutic potentials, Pharmacol. Ther. 82 (1999) 389-397.

[47] L. Zhang, F. Stuber, U.M. Stamer, Inflammatory mediators influence the expression of nociceptin and its receptor in human whole blood cultures, PLoS One 8 (2013) e74138. doi: 10.1371/journal.pone.0074138.

[48] C. Acosta, A. Davies, Bacterial lipopolysaccharide regulates nociceptin expression in sensory neurons, J. Neurosci. Res. 86 (2008) 1077-1086.

[49] M.A. Nahid, M. Satoh, E.K. Chan, MicroRNA in TLR signaling and endotoxin tolerance, Cell. Mol. Immunol. 8 (2011) 388-403. doi: 10.1038/cmi.2011.26.

[50] S. Deng, S. Zhu, Y. Qiao, Y.J. Liu, W. Chen, G. Zhao, J. Chen, Recent advances in the role of toll-like receptors and TLR agonists in immunotherapy for human glioma, Protein Cell 5 (2014) 899-911. doi: 10.1007/s13238-014-0112-6.

[51] S.H. Rhee, D. Hwang, Murine TOLL-like receptor 4 confers lipopolysaccharide responsiveness as determined by activation of NF kappa B and expression of the inducible cyclooxygenase, J. Biol. Chem. 275 (2000) 34035-34040.

[52] C. Erridge, Endogenous ligands of TLR2 and TLR4: agonists or assistants? J. Leukoc. Biol.

This item was downloaded from IRIS Università di Bologna (https://cris.unibo.it/)

When citing, please refer to the published version. 
87 (2010) 989-999. doi: 10.1189/jlb.1209775.

[53] N. Saïd-Sadier, D.M. Ojcius, Alarmins, inflammasomes and immunity, Biomed. J. 35 (2012) 437-449. doi: 10.4103/2319-4170.104408.

[54] J. Austermann, J. Friesenhagen, S.K. Fassl, B. Petersen, T. Ortkras, J. Burgmann, K. Barczyk-Kahlert, E. Faist, S. Zedler, S. Pirr, C. Rohde, C. Müller-Tidow, M. von KöckritzBlickwede, C.S. von Kaisenberg, S.B. Flohé, T. Ulas, J.L. Schultze, J. Roth, T. Vogl, D. Viemann, Alarmins MRP8 and MRP14 induce stress tolerance in phagocytes under sterile inflammatory conditions, Cell Rep. 9 (2014) 2112-2123. doi:10.1016/j.celrep.2014.11.020.

[55] L. Zhang, L. Wang, J. Jiang, D. Zheng, S. Liu, C. Liu, Lipopolysaccharides upregulate calcium concentration in mouse uterine smooth muscle cells through the T-type calcium channels, Int. J. Mol. Med. 35 (2015) 784-790. doi:10.3892/ijmm.2014.2054.

[56] I. Latour, D.F. Louw, A.M. Beedle, J. Hamid, G.R. Sutherland, ssepeig. W. Zamponi, Expression of T-type calcium channel splice variants in human glioma, Glia 48 (2004) 112-119.

[57] Y. Zhang, J. Zhang, D. Jiang, D. Zhang, Z. Qian, C. Liu, J. Tao, Inhibition of T-type Ca ${ }^{2+}$ channels by endostatin attenuates human glioblastoma cell proliferation and migration, $\mathrm{Br}$. $\mathrm{J}$. Pharmacol. 166 (2012) 1247-1260. doi:10.1111/j.1476-5381.2012.01852.x.

[58] T. Nagano, S.H. Kimura, E. Takai, T. Matsuda, M. Takemura, Lipopolysaccharide sensitizes microglia toward $\mathrm{Ca}\left({ }^{2+}\right)$-induced cell death: mode of cell death shifts from apoptosis to necrosis, Glia 53 (2006) 67-73.

[59] H. Hetschko, V. Voss, S. Horn, V. Seifert, J.H. Prehn, D. Kögel, Pharmacological inhibition of Bcl-2 family members reactivates TRAIL-induced apoptosis in malignant glioma, J. Neurooncol. 86 (2008) 265-272.

[60] L. Toll, M.R. Bruchas, G. Calo', B.M. Cox, N.T. Zaveri, Nociceptin/Orphanin FQ Receptor Structure, Signaling, Ligands, Functions, and Interactions with Opioid Systems, Pharmacol. 
Rev. 68 (2016) 419-457. doi: 10.1124/pr.114.009209.

[61] S.K. Shenoy, R. J. Lefkowitz, $\beta$-Arrestin-mediated receptor trafficking and signal transduction, Trends Pharmacol. Sci. 32 (2011) 521-533. doi:10.1016/j.tips.2011.05.002.

[62] A. do Carmo, J. Balça-Silva, D. Matias, M.C. Lopes, PKC signaling in glioblastoma, Cancer Biol. Ther. 14 (2013) 287-294. doi: 10.4161/cbt.23615.

[63] A. Zanotto-Filho, E. Braganhol, R. Schröder, L.H. de Souza, R.J. Dalmolin, M.A. Pasquali, D.P. Gelain, A.M. Battastini, J.C. Moreira, NFкB inhibitors induce cell death in glioblastomas, Biochem. Pharmacol. 81(2011) 412-424. doi:10.1016/j.bcp.2010.10.014.

[64] A.G. Vaiopoulos, K.K. Papachroni, A.G. Papavassiliou, Colon carcinogenesis: Learning from NF-kappaB and AP-1, Int. J. Biochem. Cell Biol. 42 (2010) 1061-1065. doi:10.1016/j.biocel.2010.03.018.

[65] L. Tarassishin, D. Casper, S.C. Lee, Aberrant expression of interleukin-1 $\beta$ and inflammasome activation in human malignant gliomas, PLoS One 9 (2014) e103432. doi: 10.1371/journal.pone.0103432.

[66] L. Tarassishin, J. Lim, D.B. Weatherly, R.H. Angeletti, S.C. Lee, Interleukin-1-induced changes in the glioblastoma secretome suggest its role in tumor progression, J. Proteomics 99C (2014) 152-168. doi:10.1016/j.jprot.2014.01.024.

[67] J.P. Williams, J.P. Thompson, D.J. Rowbotham, D.G. Lambert, Human peripheral blood mononuclear cells produce pre-pro-nociceptin/orphanin FQ mRNA, Anesth. Analg. 106 (2008) 865-866. doi: 10.1213/ane.0b013e3181617646.

[68] M. Al-Hashimi, J. McDonald, J.P. Thompson, D.G. Lambert, Evidence for nociceptin/orphanin FQ (NOP) but not $\mu$ (MOP), $\delta(\mathrm{DOP})$ or $\kappa(\mathrm{KOP})$ opioid receptor mRNA in whole human blood, Br. J. Anaesth. 116 (2016) 423-429. doi:10.1093/bja/aev540.

[69] E.C. Gavioli, I.U. de Medeiros, M.C. Monteiro, G. Calo, P.R. Romão, Nociceptin/orphanin This item was downloaded from IRIS Università di Bologna (https://cris.unibo.it/) 
FQ-NOP receptor system in inflammatory and immune-mediated diseases, Vitam. Horm. 97 (2015) 241-266. doi: 10.1016/bs.vh.2014.11.003.

[70] R. Thomas, C. Stover, D.G. Lambert, J.P. Thompson, Nociceptin system as a target in sepsis? J. Anesth. 28 (2014) 759-767. doi: 10.1007/s00540-014-1818-6.

[71] J. Forshammar, L. Block, C. Lundborg, B. Biber, E. Hansson, Naloxone and ouabain in ultralow concentrations restore $\mathrm{Na}+\mathrm{K}+$-ATPase and cytoskeleton in lipopolysaccharidetreated astrocytes, J. Biol. Chem. 286 (2011) 31586-31597. doi: 10.1074/jbc.M111.247767.

[72] Seeley JJ, Ghosh S. Molecular mechanisms of innate memory and tolerance to LPS. J Leukoc Biol. 2017 Jan;101(1):107-119. doi: 10.1189/jlb.3MR0316-118RR.

[73] M.A. Nahid, L.M. Benso, J.D. Shin, H. Mehmet, A. Hicks, R.A. Ramadas, TLR4, TLR7/8 agonist-induced miR-146a promotes macrophage tolerance to MyD88-dependent TLR agonists, J. Leukoc. Biol. 100 (2016) 339-349. doi: 10.1189/jlb.2A0515-197R.

[74] E.M. Quinn, J. Wang, H.P. Redmond, The emerging role of microRNA in regulation of endotoxin tolerance, J. Leukoc. Biol. 91 (2012) 721-727. doi:10.1189/jlb.1111571.

[75] H.Q. Hu, L.G. Sun, W.J. Guo, Decreased miRNA-146a in glioblastoma multiforme and regulation of cell proliferation and apoptosis by target Notch1, Int. J. Biol. Markers 31 (2016) e270-275. doi: 10.5301/jbm.5000194.

[76] J. Zhou, W. Wang, Z. Gao, X. Peng, X. Chen, W. Chen, W. Xu, H. Xu, M.C. Lin, S. Jiang, MicroRNA-155 promotes glioma cell proliferation via the regulation of MXI1, PLoS One 8 (2013) e83055. doi: 10.1371/journal.pone.0083055.

[77] J.P. Pradere, D.H. Dapito, R.F. Schwabe, The Yin and Yang of Toll-like receptors in cancer, Oncogene 33 (2014) 3485-3495. doi: 10.1038/onc.2013.302.

[78] A.E. Cherry, N. Stella, G protein-coupled receptors as oncogenic signals in glioma: emerging therapeutic avenues, Neuroscience 278 (2014) 222-236. doi:

This item was downloaded from IRIS Università di Bologna (https://cris.unibo.it/)

When citing, please refer to the published version. 
10.1016/j.neuroscience.2014.08.015.

A
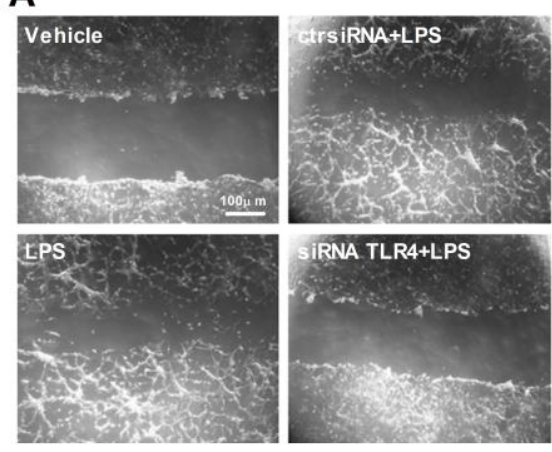

B

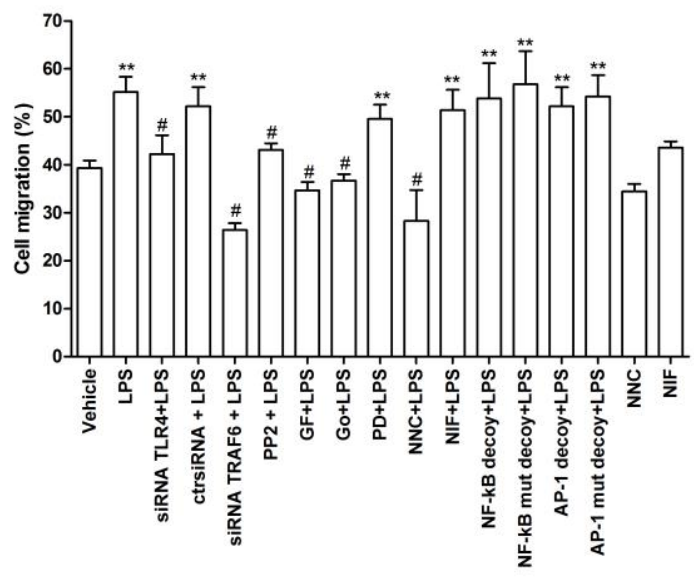

C

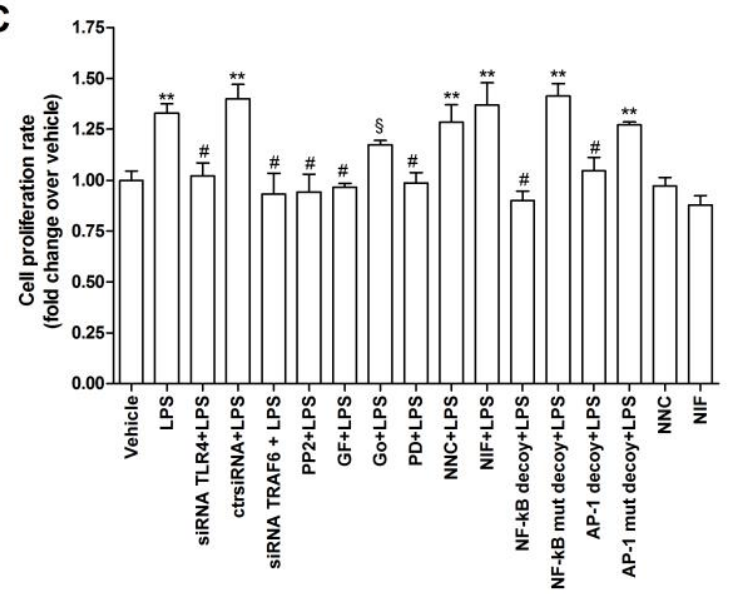

D
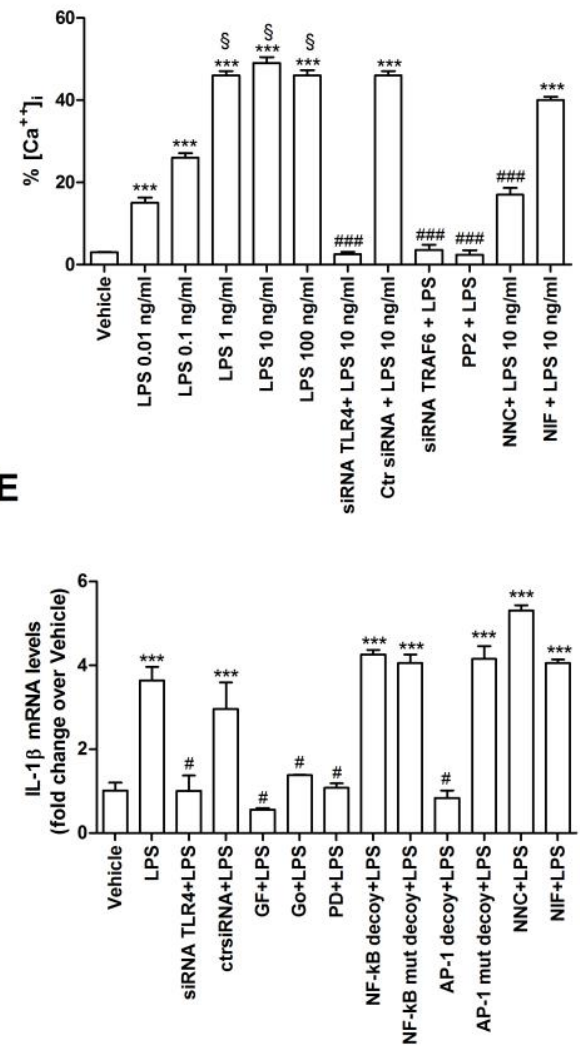

$\mathbf{F}$
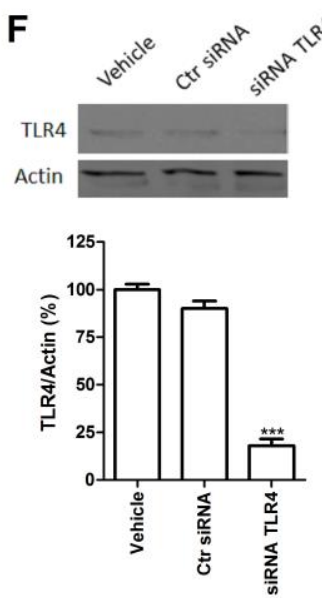

G

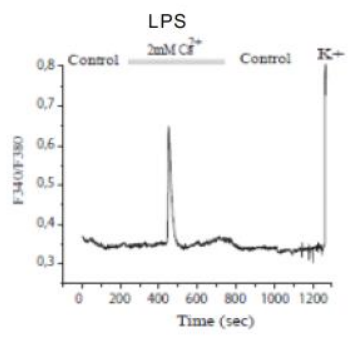


Fig. 1. Signaling pathways contributing to LPS-mediated migration, proliferation, $\left[\mathrm{Ca}^{2+}\right]_{i}$ and increase of IL$1 \beta$ of U87 glioblastoma and role of TLR4. (A) The effect of different treatments on U87 cell migration evaluated by wound closure in a scratch assay; images were acquired after $18 \mathrm{~h}$. Scale bar: $100 \mu \mathrm{m}$. Cells were maintained in serum-free medium (vehicle); LPS $(10 \mathrm{ng} / \mathrm{ml})$ promotes cell migration, and siRNA targeting TLR4 and TRAF6 prevent this effect whereas a control negative siRNA (Ctr siRNA) is ineffective. The c-Src inhibitor PP2 blocks LPS-induced cell migration. (B) Quantification of cell migration following the abovementioned treatments is reported. Furthermore, PKC inhibitors GF109203X (1 $\mu \mathrm{M})$ and Gö6976 (5 $\mu \mathrm{M})$ reduce LPS-induced migration. Conversely, PD 98059 (10 $\mu \mathrm{M})$, a blocker of ERK $1 / 2$ kinase, or decoy oligonucleotides directed against AP-1, NF-kB or their suitable controls (mut decoy) do not modify LPSmediated cell migration. (C) LPS elevates U87 cell proliferation via TLR4, as knockdown of TLR4 results in the complete abolishment of this effect. C-Src inhibitor PP2 (5 $\mu \mathrm{M})$, PKC inhibitors GF109203X (1 $\mu \mathrm{M})$ and Gö6976 (5 $\mu \mathrm{M})$ and PD $98059(10 \mu \mathrm{M})$, a blocker of ERK 1/2 kinase, reduce LPS-induced cell proliferation as do decoy oligonucleotides directed against AP-1 or against NF-kB but not their suitable controls (mut decoy). Values are the mean \pm SD from six experiments conducted in triplicate using different cell cultures. ${ }^{* *} \mathrm{P}<0.01 \mathrm{vs}$. vehicle; ${ }^{\#}<<0.01$ vs. LPS (Newman-Keuls test after ANOVA). (D) LPS induces a concentration-dependent increase in maximal $\left[\mathrm{Ca}^{2+}\right]_{i}$ rise with respect to basal levels. LPS $(10 \mathrm{ng} / \mathrm{ml})$ increases $\left[\mathrm{Ca}^{2+}\right]_{i}$ via TLR4, as it is abolished by exposure to TLR4 siRNA but not to a Ctr siRNA. Elevation of $\left[\mathrm{Ca}^{2+}\right]_{1}$ by LPS $(10 \mathrm{ng} / \mathrm{ml})$ requires TRAF6 and c-Src as it is blocked by TRAF6 siRNA and by the c-Src inhibitor PP2. NNC 55-0396 (10 $\mu \mathrm{M})$ but not nifedipine $(10 \mu \mathrm{M})$ significantly reduces the LPS-promoted $\left[\mathrm{Ca}^{2+}\right]_{i}$ increase. Data are reported as intracellular calcium increases (\% peak/basal) and presented as the mean $\pm S D\left(n=30\right.$ cells/group). ${ }^{* * *} P<0.001$ vs. vehicle; ${ }^{\S} \mathrm{P}<0.05$ vs. LPS $0.01 \mathrm{ng} / \mathrm{ml}$ and $0.1 \mathrm{ng} / \mathrm{ml}$; \#\#” $\mathrm{P}<0.001 \mathrm{vs}$. LPS $10 \mathrm{ng} / \mathrm{ml}$ (Newman-Keuls test after ANOVA). (E) LPS increases IL-1 $\beta$ mRNA levels via TLR4. PKC inhibitors GF109203X (1 $\mu \mathrm{M})$ or Gö6976 (5 $\mu \mathrm{M})$ and PD 98059 $(10 \mu \mathrm{M})$ reduce the LPS-induced increase in IL-1 $\beta$ mRNA, as does a decoy oligonucleotide directed against AP-1 but not against NF-kB; their appropriate controls do not change the LPS-induced IL-1 $\beta$ mRNA increase.

This item was downloaded from IRIS Università di Bologna (https://cris.unibo.it/)

When citing, please refer to the published version. 
Cells were maintained cell culture medium containing $10 \%$ fetal bovine serum (vehicle). Values are the mean \pm SD from six experiments conducted in triplicate using different cell cultures. (F) TLR4 expression is significantly reduced in U87 cells transfected with TLR4 siRNA but not with a control negative siRNA (Ctr siRNA). A representative immunoblot and densitometric analysis of the bands are reported. $\beta$-actin was used as an internal control. Values are the mean \pm SD from six experiments conducted using different cell cultures. ${ }^{* * *} \mathrm{P}<0.001$ vs. vehicle and Ctr siRNA (Newman-Keuls test after ANOVA). (G) Typical $\left[\mathrm{Ca}^{2+}\right]$ idynamics recorded in fura-2-loaded U87 cells exposed to $10 \mathrm{ng} / \mathrm{mI}$ LPS or to vehicle alone (Control). The viability of the cells was 
checked in every experiment by the application of a high $\mathrm{K}^{+}(50 \mathrm{mM})$ external solution.

This item was downloaded from IRIS Università di Bologna (https://cris.unibo.it/)

When citing, please refer to the published version. 


\section{A}
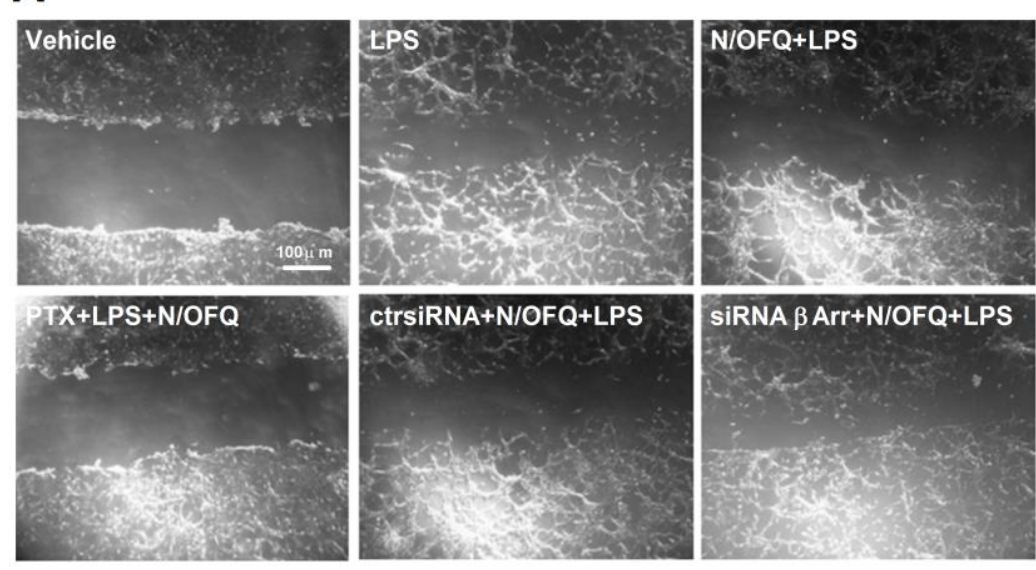

N/OFQ+NPhe+LPS

B

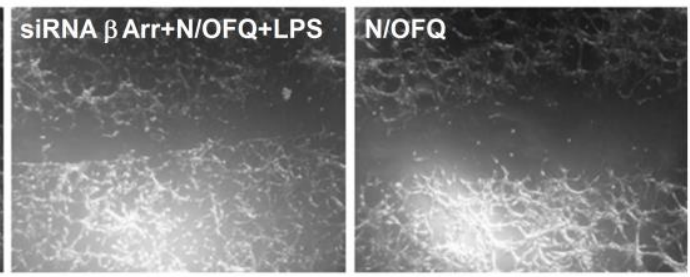

C
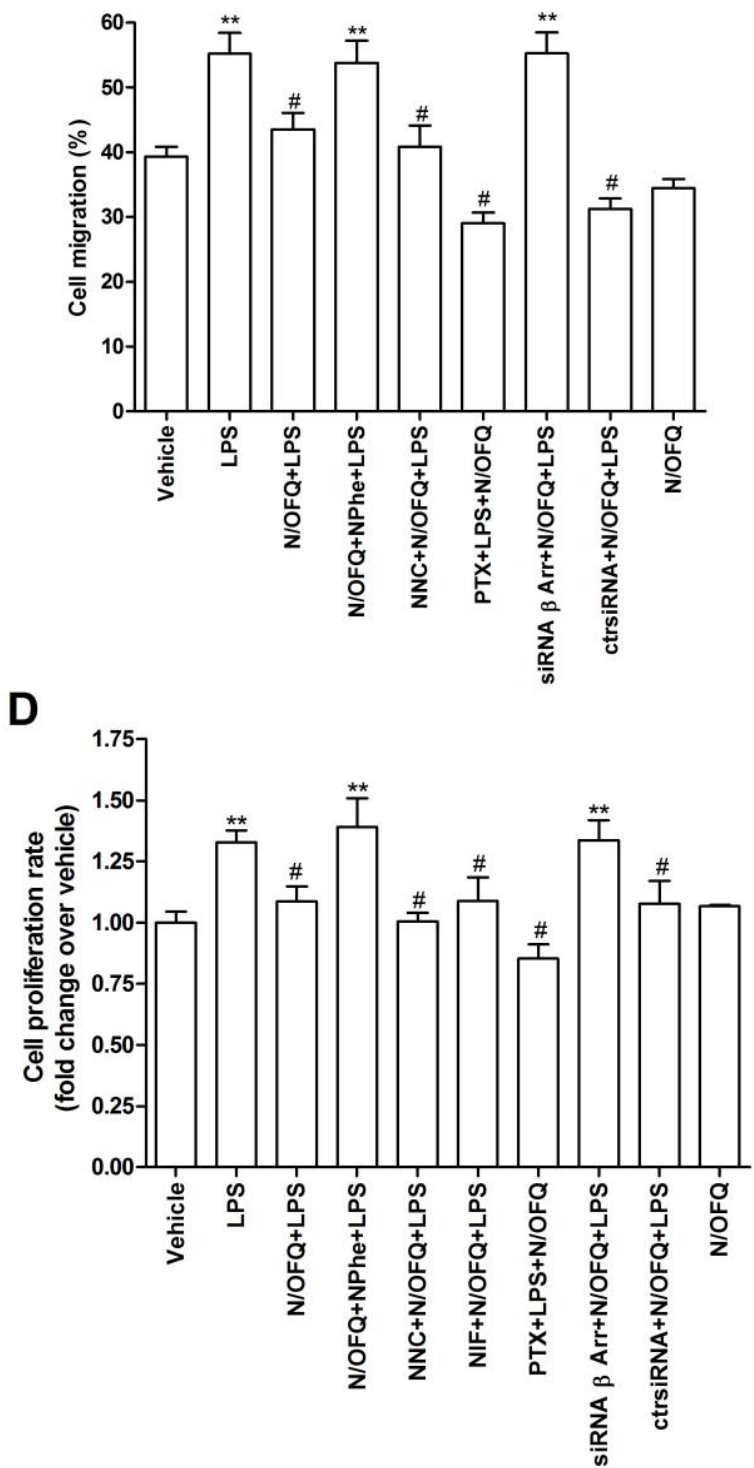

E

$\beta$ arrestin 2 Actin

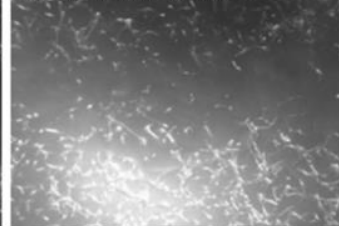

\section{N/OFQ}
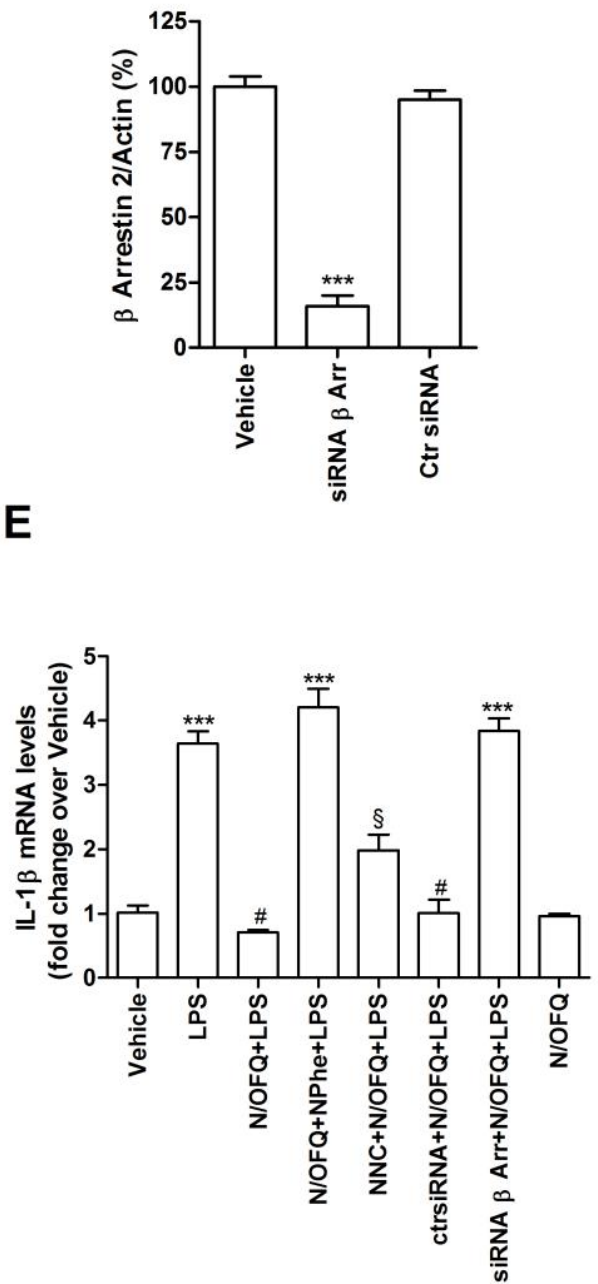

This item was downloaded from IRIS Università di Bologna (https://cris.unibo.it/) 
Fig. 2. N/OFQ attenuates the LPS-mediated migration and proliferation of U87 cells and the IL-1 $\beta$ mRNA increase. (A) The effect of different treatments on U87 cell migration evaluated by wound closure in a scratch assay; images were acquired after $18 \mathrm{~h}$. Scale bar: $100 \mu \mathrm{m}$. Cells were maintained in serum-free medium (vehicle). LPS $(10 \mathrm{ng} / \mathrm{ml})$ promotes cell migration, and N/OFQ $(1 \mu \mathrm{M})$ prevents this effect. NOP receptor antagonist [Nphe1]N/OFQ(1-13) $\mathrm{NH}_{2}(10 \mu \mathrm{M})$ prevents the N/OFQ-mediated blockade of LPS. The G $\alpha_{\mathrm{i} / \mathrm{o}}$ inhibitor PTX (10 ng/ml; $18 \mathrm{~h}$ in advance) does not modify N/OFQ blockade of LPS-induced cell migration. N/OFQ-mediated inhibition of LPS-induced migration is abolished in U87 cells transfected with siRNA silencing $\beta$-arrestin 2 but not with a control negative siRNA (Ctr siRNA). (B) Quantification of cell migration following the above-mentioned treatments is reported. Furthermore, NNC 55-0396 did not change N/OFQinduced inhibition of LPS-promoted migration. (C) $\beta$-arrestin 2 expression is significantly reduced in U87 cells transfected with $\beta$-arrestin 2 siRNA but not with a control negative siRNA (Ctr siRNA). A representative immunoblot and densitometric analysis of the bands are reported. $\beta$-actin (actin) was used as an internal control. (D) N/OFQ (1 $\mu \mathrm{M})$ blocks LPS-stimulated proliferation, an effect that is prevented by the NOP receptor antagonist [Nphe1]N/OFQ(1-13) NH 2 . NNC 55-0396 and nifedipine pretreatments, as well as PTX, do not influence LPS-promoted cell proliferation or counteract the inhibitory effect of N/OFQ upon LPSstimulated cell proliferation. N/OFQ-mediated inhibition of LPS-induced cell proliferation is abolished in U87 cells transfected with siRNA directed against $\beta$-arrestin 2 but not with a Ctr siRNA. N/OFQ added alone did not alter cell proliferation. (E) N/OFQ block the LPS-induced increase in IL-1 $\beta$ mRNA, an effect that is prevented by the NOP receptor antagonist [Nphe1]N/OFQ(1-13) NH $\mathrm{H}_{2}$ but not by NNC 55-0396 pretreatment. N/OFQ-mediated inhibition of LPS-induced IL-1 $\beta$ mRNA levels is abolished in U87 cells transfected with a siRNA directed against $\beta$-arrestin 2 but not by a CtrsiRNA. N/OFQ added alone does not modify IL-1 $\beta$ mRNA levels. Values are the mean \pm SD from six experiments conducted in triplicate using different cell cultures.

This item was downloaded from IRIS Università di Bologna (https://cris.unibo.it/)

When citing, please refer to the published version. 
${ }^{* *} \mathrm{P}<0.01 ;{ }^{* * *} \mathrm{P}<0.001$ vs. vehicle; ${ }^{\S} \mathrm{P}<0.05 ;{ }^{\# \#} \mathrm{P}<0.01$, vs. LPS (Newman-Keuls test after ANOVA).
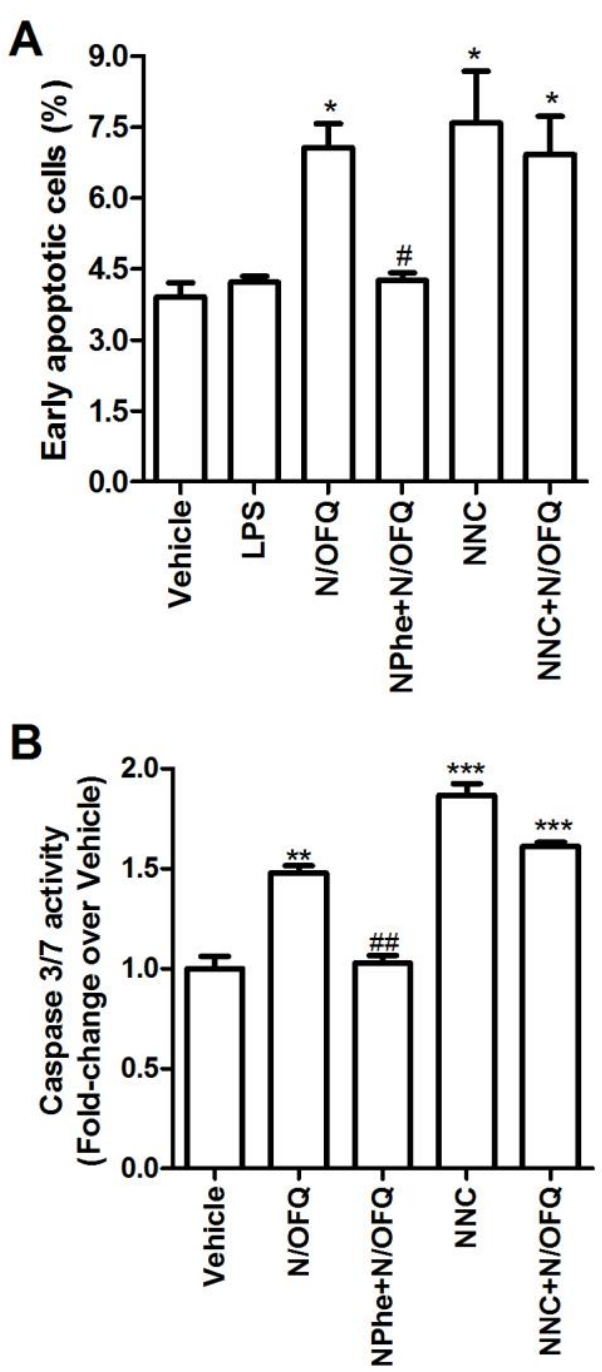

Fig. 3. N/OFQ and NNC 55-0396 promote U87 cell apoptosis. (A) N/OFQ $(1 \mu \mathrm{M})$ or NNC 55-0396 (10 $\mu \mathrm{M})$ added to U87 cells for $24 \mathrm{~h}$ significantly increase early apoptotic cells. N/OFQ occludes the apoptotic effect induced by NNC 55-0396. NOPr antagonist [Nphe1]N/OFQ(1-13) $\mathrm{NH}_{2}(10 \mu \mathrm{M})$ blocks N/OFQ-induced apoptosis, whereas LPS does not elicit any apoptotic effect. Apoptosis was determined by flow cytometry to evaluate the ability of the cell to bind annexin $V$, and the results are presented as the percentage of early

This item was downloaded from IRIS Università di Bologna (https://cris.unibo.it/)

When citing, please refer to the published version. 
apoptotic cells. (B) N/OFQ (1 $\mu \mathrm{M})$ and NNC 55-0396 (10 $\mu \mathrm{M})$ added to U87 cells for $24 \mathrm{~h}$ significantly increase caspase-3/7 activity. N/OFQ occludes the increase in caspase 3/7 activity induced by NNC 55-0396. NOP receptor antagonist [Nphe1]Nociceptin(1-13) $\mathrm{NH}_{2}(10 \mu \mathrm{M})$ blocks N/OFQ-induced caspase 3/7 activity. Cell apoptosis and Caspase-3/7 activity were measured as described in the Materials and Methods section. Cells were maintained cell culture medium containing $10 \%$ fetal bovine serum (vehicle). Values are mean \pm SD from six experiments conducted in triplicate using different cell cultures. ${ }^{*} \mathrm{P}<0.05,{ }^{* *} \mathrm{P}<0.01,{ }^{* * *} \mathrm{P}<0.001$ vs. vehicle. ${ }^{\#} \mathrm{P}<0.05 ;{ }^{\#} \mathrm{P}<0.01$, vs. N/OFQ (Newman-Keuls test after ANOVA).

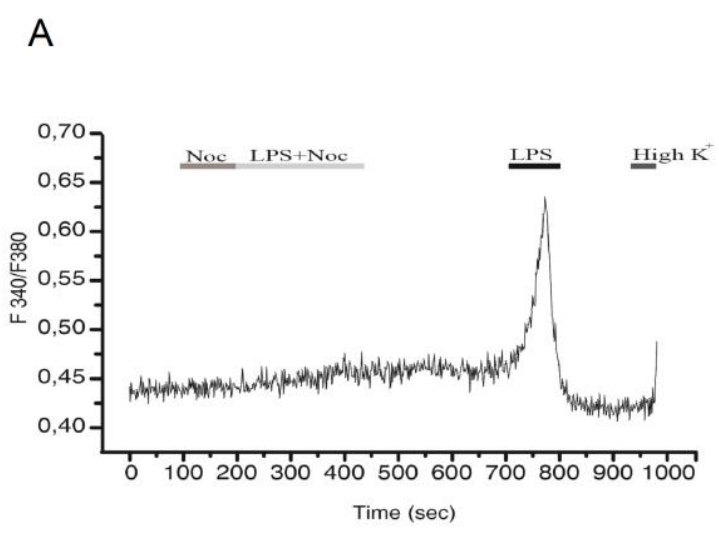

B

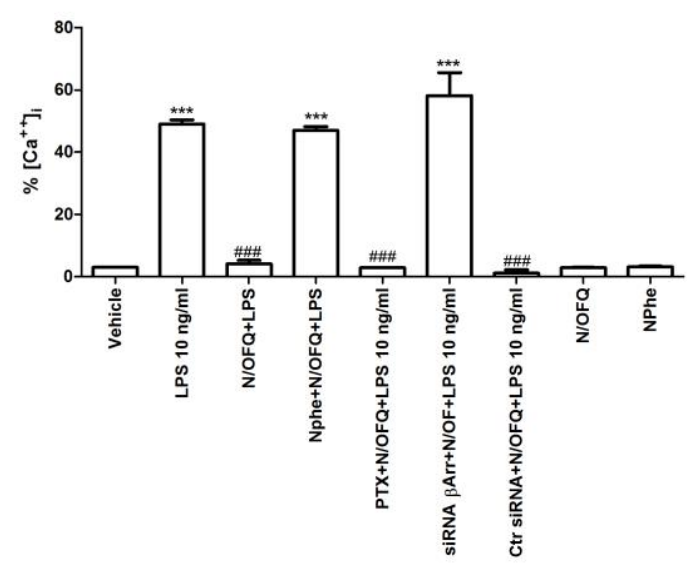

Fig. 4. N/OFQ counteracts the LPS-induced $\left[\mathrm{Ca}^{2+}\right]_{i}$ increase in U87 cells. N/OFQ (1 $\left.\mu \mathrm{M}\right)$ blocks the LPSinduced increase in $\left[\mathrm{Ca}^{2+}\right]_{1}$, an effect that is prevented by the NOP receptor antagonist [Nphe1]N/OFQ(1This item was downloaded from IRIS Università di Bologna (https://cris.unibo.it/) 
13) $\mathrm{NH}_{2}(10 \mu \mathrm{M})$. The $\mathrm{G} \alpha_{\mathrm{i} / \mathrm{o}}$ inhibitor PTX (10 ng/ml; $18 \mathrm{~h}$ in advance) does not modify N/OFQ blockade of LPSinduced $\left[\mathrm{Ca}^{2+}\right]_{i}$. N/OFQ-mediated inhibition of LPS-induced migration is abolished in U87 cells transfected with siRNA silencing $\beta$-arrestin 2 but not with a control negative siRNA (Ctr siRNA). N/OFQ and Nphe1]N/OFQ(1-13) $\mathrm{NH}_{2}$ alone do not cause any $\left[\mathrm{Ca}^{2+}\right]_{i}$ increase. Data are reported as intracellular calcium increases (\% peak/basal) and presented as the mean $\pm \mathrm{SD}\left(\mathrm{n}=30\right.$ cells/group). ${ }^{* * *} \mathrm{P}<0.001$ vs. vehicle; ${ }^{\S} \mathrm{P}<0.05$ 
A

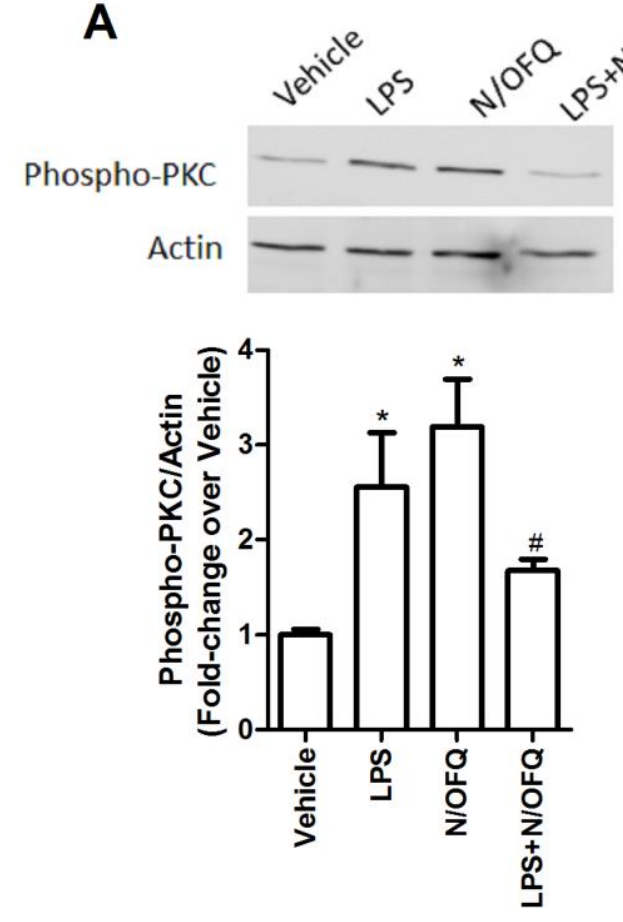

B

Phospho-ERK1/2

TOT ERK

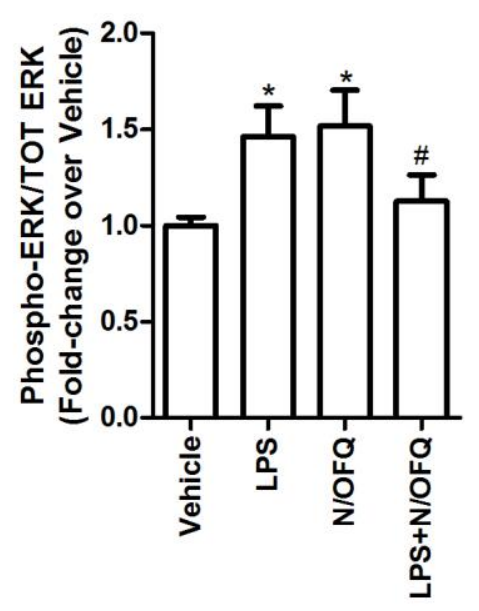


Fig. 5. N/OFQ counteracts the LPS-induced phosphorylation of PKC and ERK $1 / 2$ in U87 cells. LPS (10 ng/ml) and N/OFQ (1 $\mu \mathrm{M})$ increase PKC phosphorylation (panel A) and ERK 1/2 phosphorylation (panel B) when added alone to U87 cells. N/OFQ antagonizes LPS-induced PKC and ERK 1/2 phosphorylation. PKC and ERK $1 / 2$ phosphorylation was assayed in cells collected 60 and 15 min after treatments. Cells were maintained in serum-free medium (vehicle). Representative immunoblots and densitometric analysis of the bands (mean \pm SD; $n=6$ ) are reported. ${ }^{*} \mathrm{P}<0.05 ;{ }^{* *} \mathrm{P}<0.01$ vs. vehicle. ${ }^{\#} \mathrm{P}<0.05$ vs. LPS or N/OFQ (Newman-Keuls test after ANOVA).

A

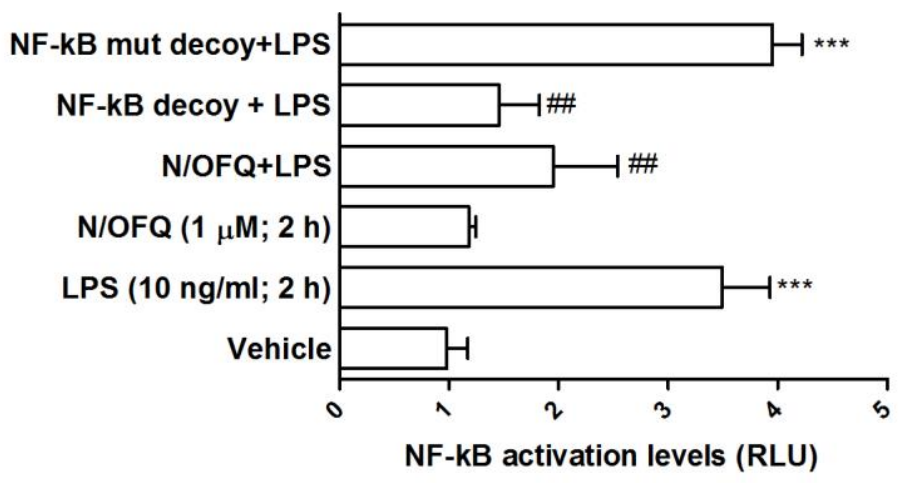

B

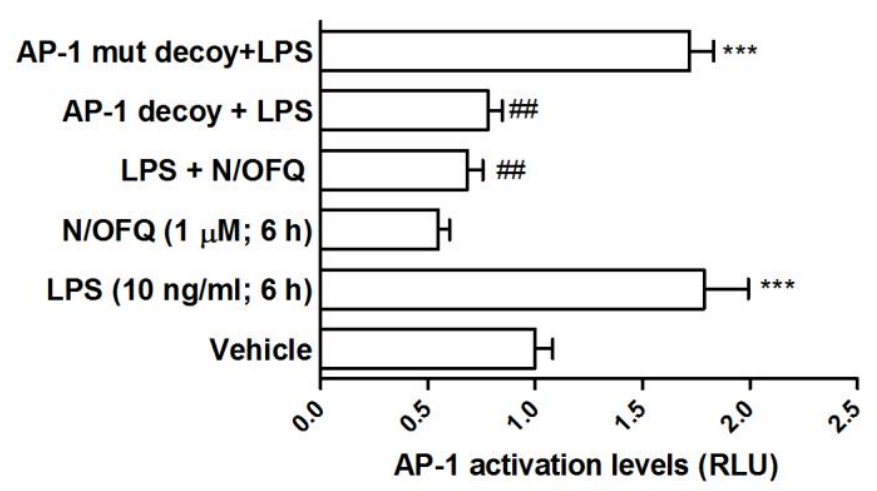

Fig. 6. N/OFQ counteracts the LPS-induced NF-kB and AP-1 transcriptional activity in U87 cells. (A) N/OFQ prevents LPS-induced NF-kB transcriptional activity. LPS-induced luciferase activity is abolished in cells This item was downloaded from IRIS Università di Bologna (https://cris.unibo.it/) 
treated with a decoy oligonucleotide directed against NF-kB and transfected with a reporter plasmid containing a NF-kB binding motif (NF-kB decoy) whereas a mutated oligonucleotide is not effective (NF-kB mut decoy). Luciferase activity was measured $2 \mathrm{~h}$ after LPS (10 ng/ml) stimulation (B) N/OFQ antagonizes LPS-induced AP-1 transcriptional activity. Induction of AP-1 reporter gene is abolished by a decoy oligonucleotide (AP-1 decoy) directed against AP-1 but not by a mutated oligonucleotide (AP-1 mut decoy). Cells were incubated with decoy or mutated oligonucleotides for $16 \mathrm{~h}$; thereafter, were transfected with plasmid containing reporter constructs and treated, $24 \mathrm{~h}$ later, with LPS $(10 \mathrm{ng} / \mathrm{ml})$. Cells were maintained in cell culture medium containing $10 \%$ fetal bovine serum (vehicle). Values are the mean \pm SD from six experiments conducted in triplicate using different cell cultures. ${ }^{* * *} \mathrm{P}<0.001$ vs. vehicle. ${ }^{\# \#} \mathrm{P}<0.01$ vs. LPS (Newman-Keuls test after ANOVA).

A

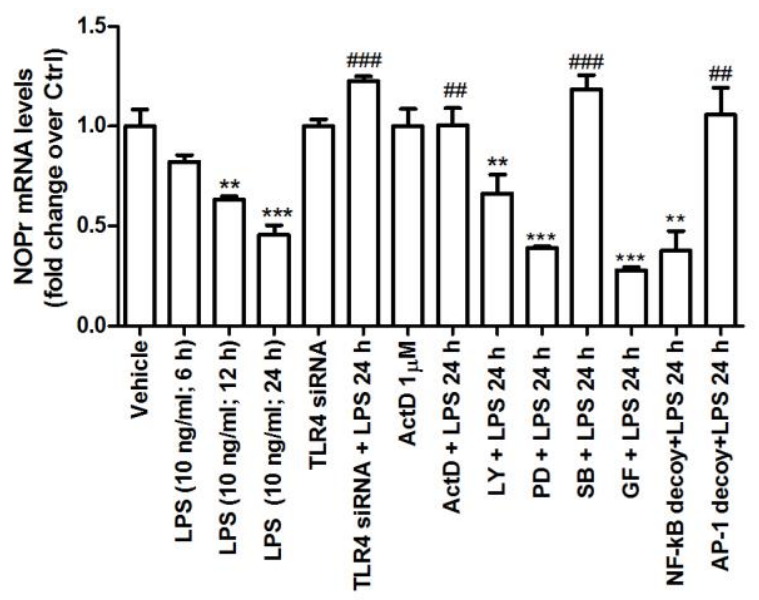

B

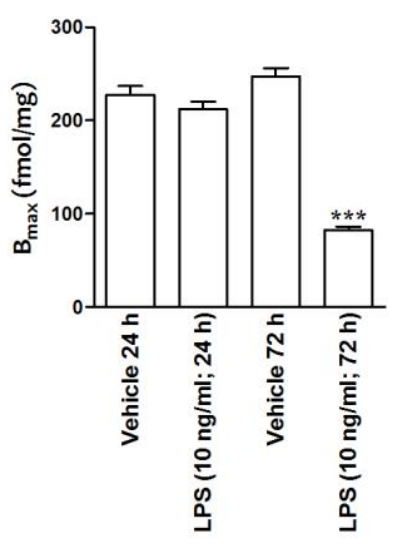

Fig. 7. LPS induces down-regulation of NOP receptor transcripts in U87 cells. (A) Relative fold changes in NOPr mRNA levels following various treatments were calculated using the $\Delta \Delta C_{t}$ method as described in the Materials and Methods section. Time-dependent exposure to LPS $(10 \mathrm{ng} / \mathrm{ml})$ decreases NOPr mRNA content. The action of LPS (10 ng/ml) on NOPr mRNA is abolished by exposure to TLR4 siRNA; the latter, when added This item was downloaded from IRIS Università di Bologna (https://cris.unibo.it/) 
alone to the cell culture for $48 \mathrm{~h}$, does not influence NOPr mRNA levels. Actinomycin D (ActD) does not change NOPr mRNA but is capable of counteracting LPS-induced down-regulation. PKC inhibitor GF109203X (GF; 1 $\mu \mathrm{M})$, the blocker of ERK 1/2 kinase, PD 98059 (PD; $10 \mu \mathrm{M})$, and the phosphatidylinositol 3-kinase inhibitor LY294002 (LY; $10 \mu \mathrm{M})$ do not affect LPS-induced NOPr mRNA down-regulation, whereas the p38MAPK inhibitor SB203580 (SB; $2 \mu \mathrm{M}$ ) is effective in preventing LPS-induced down-regulation of NOPr mRNA. A decoy oligonucleotide directed against AP-1 strongly inhibits the LPS-mediated NOP receptor mRNA reduction. Conversely, a decoy oligonucleotide directed against NF-kB receptor mRNA does not modify LPS-mediated cell migration. (B) NOPr density ( $B_{\max }$ ) is decreased in U87 cells exposed for $72 \mathrm{~h}$ to LPS $(10 \mathrm{ng} / \mathrm{ml})$, whereas a shorter exposure $(24 \mathrm{~h})$ or the vehicle were not effective. NOPr density was measured in U87 cell membranes by saturation binding assays as described under Materials and Methods. A single-site receptor binding model provided the best fit for data analysis. Cells were maintained in cell culture medium containing $10 \%$ fetal bovine serum (vehicle). Values are the mean \pm SD of at least six independent experiments conducted in triplicate using different cell cultures. ${ }^{* *} \mathrm{P}<0.01 ;{ }^{* *} \mathrm{P}<0.001$ vs vehicle; ${ }^{\# \#} \mathrm{P}<0.01 ;{ }^{\# \# \#} \mathrm{P}<0.001$ 
vs. LPS (10 ng/ml; $24 \mathrm{~h}$ ) (Newman-Keuls test after ANOVA).

A

B
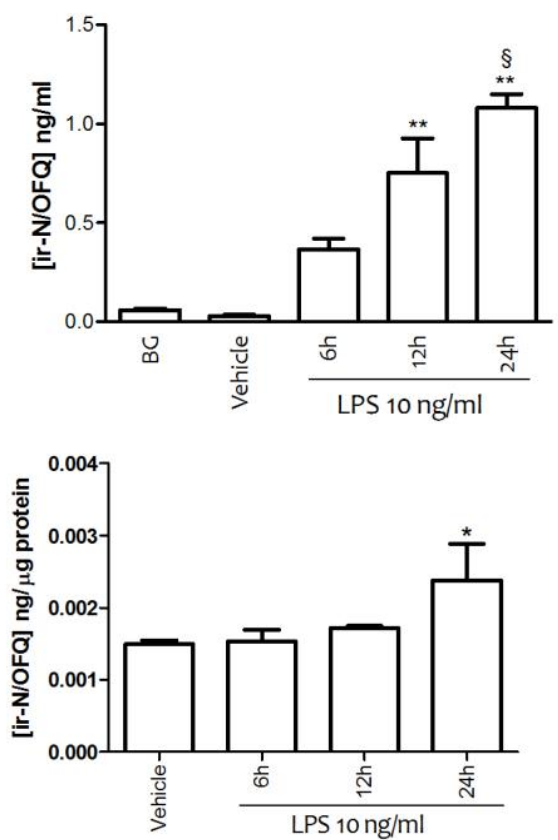

C

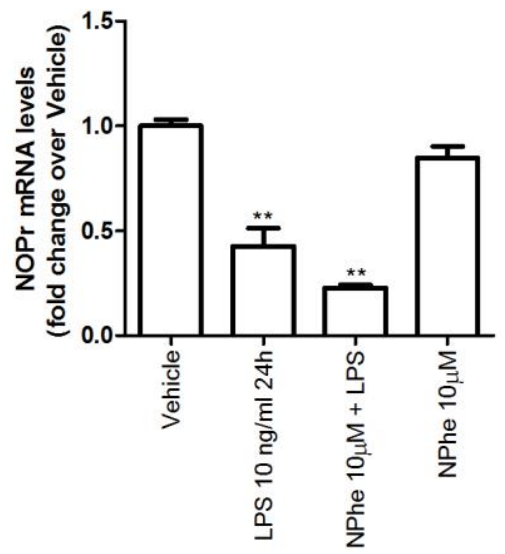

Fig. 8. LPS-mediated N/OFQ up-regulation and release do not influence NOPr mRNA down-regulation. (A) LPS induces a time-dependent release of N/OFQ in the cell culture medium. U87 cells were maintained in cell culture medium containing $10 \%$ fetal bovine serum (BG) or in serum-free cell culture medium (vehicle) or exposed to LPS (10 ng/ml) up to $24 \mathrm{~h}$. Ir-N/OFQ was measured by RIA in the cell culture medium samples as This item was downloaded from IRIS Università di Bologna (https://cris.unibo.it/) 
described in the Materials and Methods. (B) LPS induces a time-dependent increase in cell content of irN/OFQ. After incubation with LPS, the medium was collected by aspiration and the cells were harvested and homogenized in an acetic acid solution to extract the peptides for measurement of ir-N/OFQ by RIA (see Materials and Methods). (C) LPS-mediated down-regulation of NOPr mRNA in U87 cells treated for $24 \mathrm{~h}$ is not blocked by the NOPr antagonist [Nphe1]N/OFQ(1-13) $\mathrm{NH}_{2}$ (10 $\mu \mathrm{M}$; Nphe); furthermore, this compound added to the cells for $24 \mathrm{~h}$ does not influence NOPr mRNA levels. Values are the mean \pm SD from six experiments conducted in triplicate using different cell cultures. ${ }^{*} \mathrm{P}<0.05 ;{ }^{* *} \mathrm{P}<0.01$; vs. vehicle. ${ }^{\S} \mathrm{P}<0.05$ vs. 
LPS 12 h (Newman-Keuls test after ANOVA).

This item was downloaded from IRIS Università di Bologna (https://cris.unibo.it/)

When citing, please refer to the published version. 

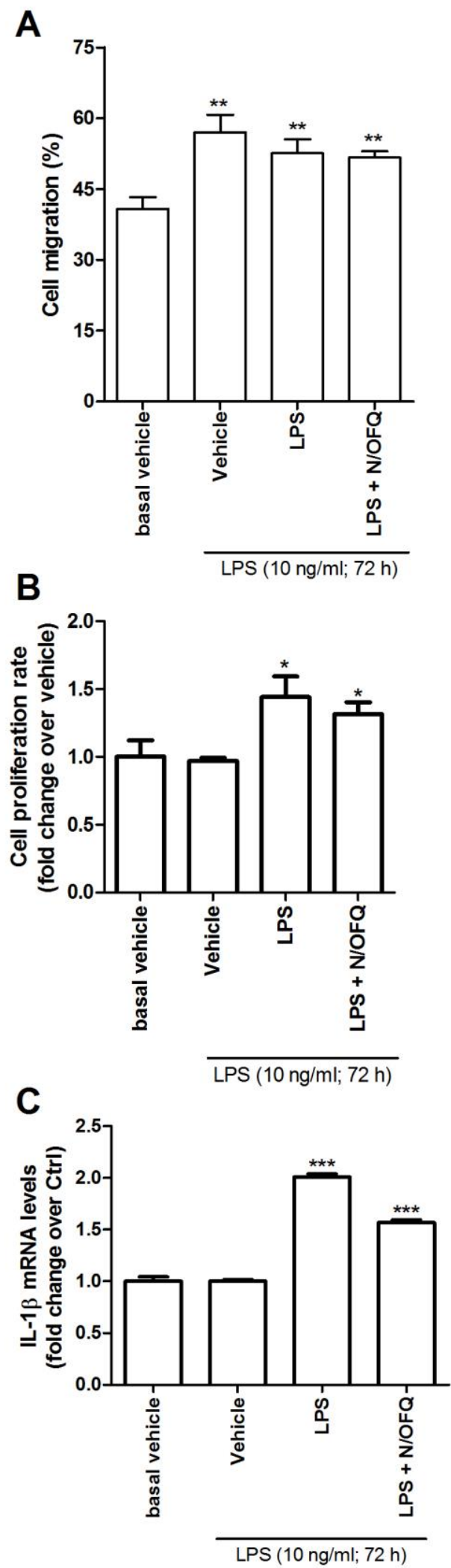

This item was downloaded from IRIS Università di Bologna (https://cris.unibo.it/)

When citing, please refer to the published version. 
Fig. 9. Prolonged exposure to LPS abolishes the inhibitory effect of N/OFQ on LPS-induced cell migration, proliferation and increase in IL-1 $\beta$ mRNA transcripts. (A) U87 cells were exposed for $72 \mathrm{~h}$ to LPS (10 $\mathrm{ng} / \mathrm{ml}$ ) and then, after a 6-h washout, exposed again to this compound for $18 \mathrm{~h}$ or left in cell culture medium alone (vehicle). Under these experimental conditions, cell migration was significantly increased in both cell groups treated rechallenged with LPS or exposed to the vehicle alone. Interestingly, N/OFQ (1 $\mu \mathrm{M})$ is not able to counteract this effect. (B) Prolonged exposure to LPS $72 \mathrm{~h}+6 \mathrm{~h}$ washout + LPS for $24 \mathrm{~h}$ produces a significant increase in cell proliferation in comparison with cells treated for $72 \mathrm{~h}$ with LPS and then challenged with cell culture medium containing $10 \%$ fetal bovine serum (vehicle). N/OFQ $(1 \mu \mathrm{M})$ is not able to counteract this effect. (C) Prolonged exposure to LPS $72 \mathrm{~h}+6 \mathrm{~h}$ washout + LPS for $24 \mathrm{~h}$ produces a significant increase in cellular IL-1 $\beta$ mRNA, and N/OFQ $(1 \mu \mathrm{M})$ is not able to counteract this effect. In cells treated for $72 \mathrm{~h}$ with LPS and then maintained in the presence of cell culture medium containing $10 \%$ fetal bovine serum (vehicle) for $24 \mathrm{~h}$, cell proliferation and levels of IL-1 $\beta$ mRNA are superimposable to those observed in cells treated with vehicle for $24 \mathrm{~h}$ (basal vehicle). Values are the mean \pm SD from six experiments conducted in triplicate using different cell cultures. ${ }^{*} \mathrm{P}<0.05 ;{ }^{* *} \mathrm{P}<0.01 ;{ }^{* * *} \mathrm{P}<0.001$ vs. vehicle (Newman-Keuls test after ANOVA).

This item was downloaded from IRIS Università di Bologna (https://cris.unibo.it/) 